Review

\title{
Recent progress in production and usage of hydrogen peroxide
}

\author{
Shunichi Fukuzumi ${ }^{\text {a,b, }}$, Yong-Min Lee ${ }^{\mathrm{a}, \mathrm{c}, \# \text {, Wonwoo Nam }}{ }^{\mathrm{a}, \$}$ \\ a Department of Chemistry and Nano Science, Ewha Womans University, Seoul 03760, Korea \\ b Graduate School of Science and Engineering, Meijo University, Nagoya, Aichi 468-8502, Japan \\ ${ }^{c}$ Research Institute for Basic Sciences, Ewha Womans University, Seoul 03760, Korea
}

\section{A R T I C L E I N F O}

\section{Article history:}

Received 22 December 2020

Accepted 22 January 2021

Available online 5 April 2021

\section{Keywords:}

Hydrogen peroxide production

Water oxidation

Dioxygen reduction

Photocatalytic oxygenation

Reaction kinetics and mechanism

\begin{abstract}
A B S T R A C T
Hydrogen peroxide has attracted increasing interest as an environmentally benign and green oxidant that can also be used as a solar fuel in fuel cells. This review focuses on recent progress in production of hydrogen peroxide by solar-light-driven oxidation of water by dioxygen and its usage as a green oxidant and fuel. The photocatalytic production of hydrogen peroxide is made possible by combining the $2 \mathrm{e}^{-}$and $4 \mathrm{e}^{-}$oxidation of water with the $2 \mathrm{e}^{-}$reduction of dioxygen using solar energy. The catalytic control of the selectivity of the $2 \mathrm{e}^{-} v s$. $4 \mathrm{e}^{-}$oxidation of water is discussed together with the selectivity of the $2 \mathrm{e}^{-} v s$. $4 \mathrm{e}^{-}$reduction of dioxygen. The combination of the photocatalytic $2 \mathrm{e}^{-}$ oxidation of water and the $2 \mathrm{e}^{-}$reduction of dioxygen provides the best efficiency because both processes afford hydrogen peroxide. The solar-light-driven hydrogen peroxide production by oxidation of water and by reduction of dioxygen is combined with the catalytic oxidation of substrates with hydrogen peroxides, in which dioxygen is used as the greenest oxidant.
\end{abstract}

(C) 2021, Dalian Institute of Chemical Physics, Chinese Academy of Sciences. Published by Elsevier B.V. All rights reserved.

\section{Introduction}

Hydrogen peroxide $\left(\mathrm{H}_{2} \mathrm{O}_{2}\right)$ is an environmentally benign oxidant, being widely used for pulp- and paper-bleaching [1,2], wastewater treatment [3-6], oxidation of substrates [7-14], and fuel in fuel cells [15-20]. $\mathrm{H}_{2} \mathrm{O}_{2}$ is currently manufactured mainly by the anthraquinone process, in which an anthraquinone (such as 2-ethylanthraquinone or the 2-amyl derivative) is reduced by hydrogen $\left(\mathrm{H}_{2}\right)$ to the corresponding anthrahydroquinone using a palladium catalyst [21-23]. The anthrahydroquinone then undergoes autoxidation by dioxygen $\left.\mathrm{O}_{2}\right)$ to generate $\mathrm{H}_{2} \mathrm{O}_{2}$, accompanied by re-production of the anthraquinone. The high cost of the anthraquinone process resulting from recycling of the extraction solvents, the hydrogenation catalyst and the expensive quinone has precluded the much wider use of $\mathrm{H}_{2} \mathrm{O}_{2}$ as a green oxidant and fuel. Direct synthesis of $\mathrm{H}_{2} \mathrm{O}_{2}$ from a mixture of $\mathrm{H}_{2}$ and $\mathrm{O}_{2}$ has provided an alternative route for the on-site generation [24-29]. However, $\mathrm{H}_{2}$ and $\mathrm{O}_{2}$ gases need to be diluted in high-pressure $\mathrm{CO}_{2}$ or $\mathrm{N}_{2}$ solution to prevent serious fire hazard, substantially lowering the yields of $\mathrm{H}_{2} \mathrm{O}_{2}$ [24-29]. On the other hand, electrochemical $2 \mathrm{e}^{-}$reduction of $\mathrm{O}_{2}$ has received increasing attention because of the research development on fuel cells [30-37]. A direct electrosynthesis strategy has recently been reported by delivering separate $\mathrm{H}_{2}$ and $\mathrm{O}_{2}$ streams to an anode and cathode parted by a porous solid electrolyte, wherein the electrochemically formed $\mathrm{H}^{+}$and $\mathrm{HO}_{2}{ }^{-}$recombine to produce pure aqueous $\mathrm{H}_{2} \mathrm{O}_{2}$ solutions [38]. Because of the high cost of storage and transport of hydrogen

\footnotetext{
* Corresponding author. E-mail: fukuzumi@chem.eng.osaka-u.ac.jp

\# Corresponding author. E-mail: yomlee@ewha.ac.kr

\$Corresponding author. E-mail: wwnam@ewha.ac.kr

This work was supported by the JSPS KAKENHI (16H02268) from MEXT, Japan and by the CRI (2012R1A3A2048842) and Basic Science Research Program (NRF-2020R1I1A1A01074630) through NRF of Korea. DOI: 10.1016/S1872-2067(20)63767-6 | http://www.sciencedirect.com/journal/chinese-journal-of-catalysis | Chin. J. Catal., Vol. 42, No. 8, August 2021
} 
gas, the electrolyzer type cell is preferred. However, higher cell voltages and electricity cost are required to drive the reaction to produce $\mathrm{H}_{2} \mathrm{O}_{2}$ [38]. Thus, the production of $\mathrm{H}_{2} \mathrm{O}_{2}$ by photocatalysis is a more sustainable process, because $\mathrm{H}_{2} \mathrm{O}$ and $\mathrm{O}_{2}$ are the earth-abundant and environmentally benign source materials and solar-light is used as the energy to drive the reaction between $\mathrm{H}_{2} \mathrm{O}$ and $\mathrm{O}_{2}$ [39-49]. This review focuses on recent mechanistic insights in solar-light-driven $\mathrm{H}_{2} \mathrm{O}_{2}$ production by oxidation of $\mathrm{H}_{2} \mathrm{O}$ and by reduction of $\mathrm{O}_{2}$ as well as the usage of $\mathrm{H}_{2} \mathrm{O}_{2}$ as a green oxidant and fuel.

\section{2. $4 \mathrm{e}^{-} \mathrm{H}_{2} \mathrm{O}$ oxidation combined with $2 \mathrm{e}^{-} \mathrm{O}_{2}$ reduction}

The first example of the photocatalytic $\mathrm{H}_{2} \mathrm{O}_{2}$ production by $4 \mathrm{e}^{-} \mathrm{H}_{2} \mathrm{O}$ oxidation combined with $2 \mathrm{e}^{-} \mathrm{O}_{2}$ reduction without hole scavengers was reported by combination of photoinduced electron transfer (ET) from the excited state of Ru(II) complex, $\left[\mathrm{Ru}^{\mathrm{II}}(4,7-\mathrm{Me} 2 \mathrm{phen})_{3}\right]^{2+*}\left(^{*}\right.$ denotes the excited state and 4,7-Me 2 phen = 4,7-dimethyl-1,10-phenanthroline) to $\mathrm{O}_{2}$ in the presence of an acid and the catalytic $4 \mathrm{e}^{-}$oxidation of $\mathrm{H}_{2} \mathrm{O}$ by $\left[\mathrm{Ru}^{\mathrm{III}}\left(4,7-\mathrm{Me}_{2} \text { phen) }\right]_{3}\right]^{3+}$ with a $\mathrm{H}_{2} \mathrm{O}$ oxidation catalyst (WOC) as shown in Scheme 1 [50]. ET from the photoexcited state of $\mathrm{Ru}(\mathrm{II})$ complex $\left(\mathrm{Ru}^{2+*}\right)$ to $\mathrm{O}_{2}$ produces $\mathrm{Ru}(\mathrm{III})$ complex and $\mathrm{O}_{2}{ }^{--}$ species. $\mathrm{O}_{2} \cdot$ - is protonated in the presence of an acid to produce hydrogen peroxyl radical $\left(\mathrm{HO}_{2}{ }^{\circ}\right)$, which disproportionates to yield $\mathrm{H}_{2} \mathrm{O}_{2}$ and $\mathrm{O}_{2}$ [50]. A diversity of metal complexes and nanoparticles (NPs) is capable of catalyzing the $4 \mathrm{e}^{-} / 4 \mathrm{H}^{+} \mathrm{H}_{2} \mathrm{O}$ oxidation by the $\mathrm{Ru}(\mathrm{II})$ photocatalyst to produce $\mathrm{O}_{2}$ [51-61]. Hence, the net reaction of the photocatalytic $2 \mathrm{e}^{-} / 2 \mathrm{H}^{+} \mathrm{O}_{2}$ reduction and the catalytic $4 \mathrm{e}^{-} / 4 \mathrm{H}^{+} \mathrm{H}_{2} \mathrm{O}$ oxidation is the photocatalytic $\mathrm{H}_{2} \mathrm{O}$ oxidation combined with $\mathrm{O}_{2}$ reduction to produce $\mathrm{H}_{2} \mathrm{O}_{2}$ [50]. When $\left[\left(\mathrm{Cp}^{*}\right) \text { (bpy)Co }{ }^{\mathrm{III}}\left(\mathrm{H}_{2} \mathrm{O}\right)\right]^{2+}$ (bpy $=2,2^{\prime}$-bipyridine and $\mathrm{Cp}^{*}=\eta^{5}$-pentamethylcyclopentadienyl) was used as a WOC with a photocatalyst, $\left[\mathrm{Ru}^{\mathrm{II}}\left(4,7-\mathrm{Me}_{2} \text { phen }\right)_{3}\right]^{2+}$, for the $2 \mathrm{e}^{-} / 2 \mathrm{H}^{+} \mathrm{O}_{2}$ reduction in $\mathrm{H}_{2} \mathrm{O}$ containing $\mathrm{Sc}^{\mathrm{III}}\left(\mathrm{NO}_{3}\right)_{3}$, the quantum yield $(\Phi)$ of the photocatalytic $\mathrm{H}_{2} \mathrm{O}_{2}$ production at $\lambda=450 \mathrm{~nm}$ was determined as $37 \%$ [50]. The solar energy conversion efficiency of $\mathrm{H}_{2} \mathrm{O}_{2}$ production was determined using simulated solar-light ( 1 sun) to be $0.25 \%$ [50]. The solar-light-driven $\mathrm{H}_{2} \mathrm{O}_{2}$ production proceeds via photoinduced ET from the $\mathrm{Ru}(\mathrm{II})^{*}$ to $\mathrm{O}_{2}$ to produce $\mathrm{Ru}(\mathrm{III})$ complex and $\mathrm{O}_{2}{ }^{--}$species that binds to $\mathrm{Sc}^{3+}$ to produce $\mathrm{O}_{2}{ }^{--}-\mathrm{Sc}^{3+}$ [62-64], which disproportionates in $\mathrm{H}_{2} \mathrm{O}$ to yield $\mathrm{H}_{2} \mathrm{O}_{2}$, while $\mathrm{H}_{2} \mathrm{O}$ is oxidized to $\mathrm{O}_{2}$ by four equivalents of $\mathrm{Ru}(\mathrm{III})$ photocatalyst with a WOC [50].

The photodriven production of $\mathrm{H}_{2} \mathrm{O}_{2}$ by oxidation of $\mathrm{H}_{2} \mathrm{O}$ by $\mathrm{O}_{2}$ was also achieved using $\mathrm{NiFe}_{2} \mathrm{O}_{4}$ NPs composed of

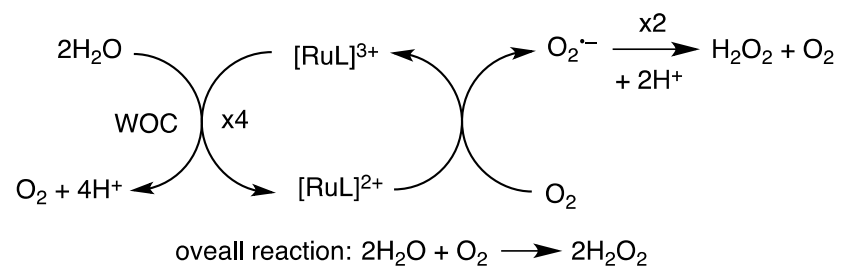

Scheme 1. Photodriven $4 \mathrm{e}^{-} \mathrm{H}_{2} \mathrm{O}$ oxidation combined with $2 \mathrm{e}^{-} \mathrm{O}_{2}$ reduction to produce $\mathrm{H}_{2} \mathrm{O}_{2}$ with WOC and $\left[\mathrm{Ru}\left(4,7-\mathrm{Me}_{2} \text { phen }\right)_{3}\right]^{2+}$ as a photocatalyst. Reproduced from Ref. [50] with permission from Royal Society of Chemistry (Copyright 2013). earth-abundant metal ions as a WOC [65], $\left[\mathrm{Ru}^{\mathrm{II}}\left(4,7-\mathrm{Me}_{2} \text { phen }\right)_{3}\right]^{2+}$ as a photocatalyst in $\mathrm{H}_{2} \mathrm{O}$ containing $\mathrm{Sc}^{\mathrm{III}}\left(\mathrm{NO}_{3}\right)_{3}$ under visible-light illumination $(\lambda>420 \mathrm{~nm})$ (Fig. 1 (a)) [66]. $\mathrm{NiFe}_{2} \mathrm{O}_{4}$ NPs catalyst could be recycled by repeatedly adding $\mathrm{Ru}(\mathrm{II})$ complex to the reaction solution after cessation of production of $\mathrm{H}_{2} \mathrm{O}_{2}$ due to the decomposition of $\mathrm{Ru}$ (II) complex. The $\mathrm{H}_{2} \mathrm{O}_{2}$ concentration increased to reach $3.3 \mathrm{mM}$, indicating the high stability of $\mathrm{NiFe}_{2} \mathrm{O}_{4}$ NPs (Fig. 1(b)) [66]. The initial rate of $\mathrm{H}_{2} \mathrm{O}_{2}$ production with use of $\mathrm{NiFe}_{2} \mathrm{O}_{4}$ NPs with diameters of 120 and $91 \mathrm{~nm}$ was 22 and 33 times faster, respectively, as compared to that with use of $\mathrm{NiFe}_{2} \mathrm{O}_{4} \mathrm{NPs}$ with a diameter of $1300 \mathrm{~nm}$ (Fig. 1(a)) [66]. Such an increase in catalytic reactivity occurs due to the increase in surface area of the WOC [66].

Heteropolynuclear cyanide metal complexes containing different metals such as $\mathrm{Fe}_{3}\left[\mathrm{Co}^{\mathrm{III}}(\mathrm{CN})_{6}\right]_{2}$ act as WOCs in the photocatalytic $\mathrm{H}_{2} \mathrm{O}_{2}$ production by oxidation of $\mathrm{H}_{2} \mathrm{O}$ by $\mathrm{O}_{2}$ with a photocatalyst, $\left[\mathrm{Ru}^{\mathrm{II}}(4,7-\mathrm{Me} 2 \mathrm{phen})_{3}\right]^{2+}$, and a Lewis acid, $\mathrm{Sc}{ }^{\mathrm{III}}\left(\mathrm{NO}_{3}\right)_{3}$, under visible-light illumination $(\lambda>420 \mathrm{~nm})$ in $\mathrm{H}_{2} \mathrm{O}$ [67]. The catalytic reactivity was improved by changing the Fe-to-Co ratio in the $\left(\mathrm{Fe}_{x}{ }_{x} \mathrm{Co}^{\mathrm{II}}{ }_{1-x}\right)$ moiety of $\left(\mathrm{Fe}^{\mathrm{II}}{ }_{x} \mathrm{Co}^{\mathrm{II}}{ }_{1-x}\right)_{3}\left[\mathrm{Co}^{\mathrm{III}}(\mathrm{CN})_{6}\right]_{2}$ and the maximum catalytic reactivity was obtained with the Fe-to-Co ratio of 0.75 [67]. A larger Fe ratio in the $\left(\mathrm{Fe}^{\mathrm{II}} \mathrm{CO}^{\mathrm{II}_{1-x}}\right)$ moiety would have more active sites for the $\mathrm{H}_{2} \mathrm{O}$ oxidation catalysis, whereas a smaller Fe ratio would stabilize high-valent metals formed during the catalytic $\mathrm{H}_{2} \mathrm{O}$ oxidation [67]. Such two opposite effects of $\mathrm{Fe}$ in $\mathrm{H}_{2} \mathrm{O}$ oxidation catalysis was balanced to obtain the best ratio of $\mathrm{Fe}(x=$ $0.75)$ in $\left(\mathrm{Fe}^{\mathrm{II}}{ }_{x} \mathrm{Co}^{\mathrm{II}}{ }_{1-x}\right)_{3}\left[\mathrm{Co}^{\mathrm{III}}(\mathrm{CN})_{6}\right]_{2}$ for the photocatalytic $\mathrm{H}_{2} \mathrm{O}_{2}$ production [67].

Polymeric CN-bridged heteronuclear metal complexes, $\mathrm{M}(\mathrm{II})\left[\mathrm{Ru}(\mathrm{II})(\mathrm{CN})_{4}(\mathrm{bpy})\right](\mathrm{M}(\mathrm{II})=\mathrm{Ni}(\mathrm{II}), \mathrm{Fe}(\mathrm{II})$ and $\mathrm{Mn}(\mathrm{II}))$, act as bifunctional catalysts for both the $4 \mathrm{e}^{-} / 4 \mathrm{H}^{+} \mathrm{H}_{2} \mathrm{O}$ oxidation to $\mathrm{O}_{2}$ and the $2 \mathrm{e}^{-} / 2 \mathrm{H}^{+} \mathrm{O}_{2}$ reduction to $\mathrm{H}_{2} \mathrm{O}_{2}$ in photocatalytic $\mathrm{H}_{2} \mathrm{O}_{2}$ production by oxidation of $\mathrm{H}_{2} \mathrm{O}$ by $\mathrm{O}_{2}$ [68]. The highest TON (turnover number) of 247 was obtained based on the monomer unit of $\mathrm{Ni}(\mathrm{II})\left[\mathrm{Ru}(\mathrm{II})(\mathrm{CN})_{4}(\mathrm{bpy})\right]$ that was employed as a bifunction photocatalyst for the $\mathrm{H}_{2} \mathrm{O}_{2}$ production by oxidation of $\mathrm{H}_{2} \mathrm{O}$
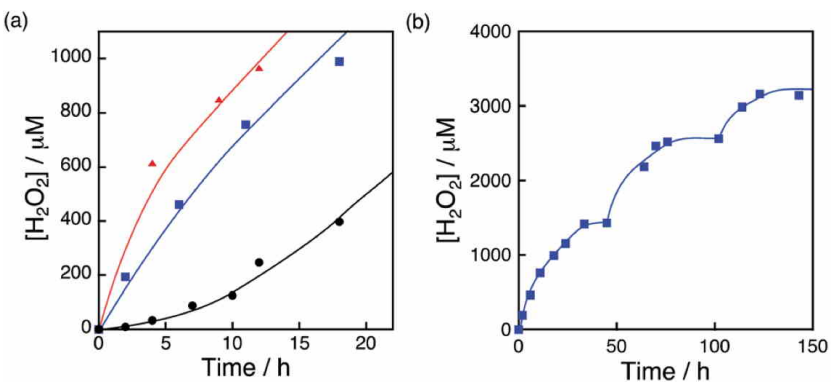

Fig. 1. (a) Time profiles of photodriven $\mathrm{H}_{2} \mathrm{O}_{2}$ production under illumination $(\lambda>420 \mathrm{~nm})$ of an $\mathrm{O}_{2}$-saturated aqueous solution containing $\left[\mathrm{Ru}^{\mathrm{II}}\left(4,7-\mathrm{Me}_{2} \text { phen }\right)_{3}\right]^{2+}(0.20 \mathrm{mM}), \mathrm{Sc}^{\mathrm{III}}\left(\mathrm{NO}_{3}\right)_{3}(0.10 \mathrm{M})$ and $\mathrm{NiFe}_{2} \mathrm{O}_{4} \mathrm{NPs}$ $(0.17 \mathrm{~g} / \mathrm{L})$ with diameters of 1300 (black), 120 (blue) and $91 \mathrm{~nm}$ (red); (b) Time profile of photodriven $\mathrm{H}_{2} \mathrm{O}_{2}$ production under illumination $(\lambda$ $>420 \mathrm{~nm}$ ) of an $\mathrm{O}_{2}$-saturated aqueous solution containing $\mathrm{Ru}(\mathrm{II})(0.20$ $\mathrm{mM}), \mathrm{Sc}^{\mathrm{III}}\left(\mathrm{NO}_{3}\right)_{3}(0.10 \mathrm{M})$ and $\mathrm{NiFe}_{2} \mathrm{O}_{4} \mathrm{NPs}(0.17 \mathrm{~g} / \mathrm{L}) . \mathrm{Ru}(\mathrm{II})$ complex was added to the reaction solution at 50 and $100 \mathrm{~h}$ during the visible-light-driven $\mathrm{H}_{2} \mathrm{O}_{2}$ production. Reproduced from Ref. [66] with permission from Royal Society of Chemistry (Copyright 2015). 


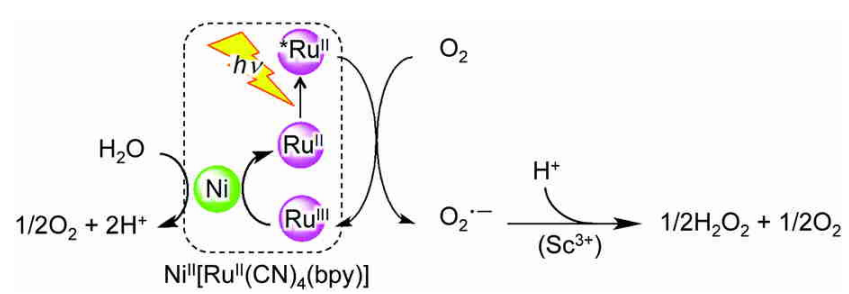

Scheme 2. Photocatalytic cycle of photodriven $\mathrm{H}_{2} \mathrm{O}_{2}$ production by oxidation of $\mathrm{H}_{2} \mathrm{O}$ by $\mathrm{O}_{2}$ with $\mathrm{Ni}(\mathrm{II})\left[\mathrm{Ru}(\mathrm{II})(\mathrm{CN})_{4}(\right.$ bpy)]. Reproduced from Ref. [68] with permission from Royal Society of Chemistry (Copyright 2017).

by $\mathrm{O}_{2}$ in $\mathrm{CH}_{3} \mathrm{OH} / \mathrm{H}_{2} \mathrm{O}(5: 1 \mathrm{v} / \mathrm{v})$ containing $\mathrm{Sc}^{\mathrm{III}}\left(\mathrm{NO}_{3}\right)_{3}$ under illumination $(\lambda>390 \mathrm{~nm})$ [68]. $\mathrm{No}_{2} \mathrm{H}_{2}$ was produced in pure $\mathrm{CH}_{3} \mathrm{OH}$, manifesting that water is the electron source of $\mathrm{O}_{2}$ reduction [68]. The catalytic mechanism of the photocatalytic $\mathrm{H}_{2} \mathrm{O}_{2}$ production with $\mathrm{Ni}(\mathrm{II})\left[\mathrm{Ru}(\mathrm{II})(\mathrm{CN})_{4}(\mathrm{bpy})\right]$ is proposed as shown in Scheme 2 [68], where ET from the photoexcited state of $\mathrm{Ni}(\mathrm{II})\left[\mathrm{Ru}(\mathrm{II})(\mathrm{CN})_{4}(\mathrm{bpy})\right]$ to $\mathrm{O}_{2}$ with $\mathrm{Sc}^{3+}$ to produce $\left[\mathrm{Ni}(\mathrm{II})\left[\mathrm{Ru}(\mathrm{III})(\mathrm{CN})_{4}(\mathrm{bpy})\right]\right]^{+}$and $\mathrm{O}_{2}{ }^{--}-\mathrm{Sc}^{3+}$ that disproportionates with $\mathrm{H}^{+}$to produce $\mathrm{H}_{2} \mathrm{O}_{2}$ [68]. Four equivalents of the $\mathrm{Ru}(\mathrm{III})$ moiety in $\left[\mathrm{Ni}(\mathrm{II})\left[\mathrm{Ru}(\mathrm{III})(\mathrm{CN})_{4}(\mathrm{bpy})\right]\right]^{+}$oxidize water by the catalysis of the $\mathrm{Ni}$ moiety in $\mathrm{Ni}(\mathrm{II})\left[\mathrm{Ru}(\mathrm{II})(\mathrm{CN})_{4}(\mathrm{bpy})\right]$ to evolve $\mathrm{O}_{2}$ [68]. The dual function of $\mathrm{M}(\mathrm{II})\left[\mathrm{Ru}(\mathrm{II})(\mathrm{CN})_{4}(\mathrm{bpy})\right]$ as a single catalyst for the $4 \mathrm{e}^{-} / 4 \mathrm{H}^{+} \mathrm{H}_{2} \mathrm{O}$ oxidation and the $2 \mathrm{e}^{-} / 2 \mathrm{H}^{+}$ $\mathrm{O}_{2}$ reduction provides an efficient integrated way to produce $\mathrm{H}_{2} \mathrm{O}_{2}$ by photocatalytic oxidation of $\mathrm{H}_{2} \mathrm{O}$ by $\mathrm{O}_{2}$.

Hydrogen peroxide production by combining the catalytic $4 \mathrm{e}^{-} / 4 \mathrm{H}^{+} \mathrm{H}_{2} \mathrm{O}$ oxidation to $\mathrm{O}_{2}$ and the photocatalytic $2 \mathrm{e}^{-} / 2 \mathrm{H}^{+} \mathrm{O}_{2}$ reduction to $\mathrm{H}_{2} \mathrm{O}_{2}$ using the same homogeneous solution described above inevitably competed with the further oxidation of $\mathrm{H}_{2} \mathrm{O}_{2}$ with a WOC to preclude production of $\mathrm{H}_{2} \mathrm{O}_{2}$ that is stable enough to obtain high concentrations ( $>10 \mathrm{mM}$ ). Hence, the photocatalytic $\mathrm{H}_{2} \mathrm{O}_{2}$ production by oxidation of $\mathrm{H}_{2} \mathrm{O}$ by $\mathrm{O}_{2}$ was performed with use of a two-compartment cell that consists of a semiconductor photocatalyst anode, which was separated by a Nafion membrane from a carbon cloth cathode in the presence of $\mathrm{Ru}$ complexes and $\mathrm{Sc}$ III $\left(\mathrm{NO}_{3}\right)_{3}$ in an $\mathrm{O}_{2}$-saturated aqueous solution to obtain high concentrations of $\mathrm{H}_{2} \mathrm{O}_{2}$ in contrast to those with a one-compartment cell [69]. A schematic representation of such a two-compartment cell is shown in Fig. 2,

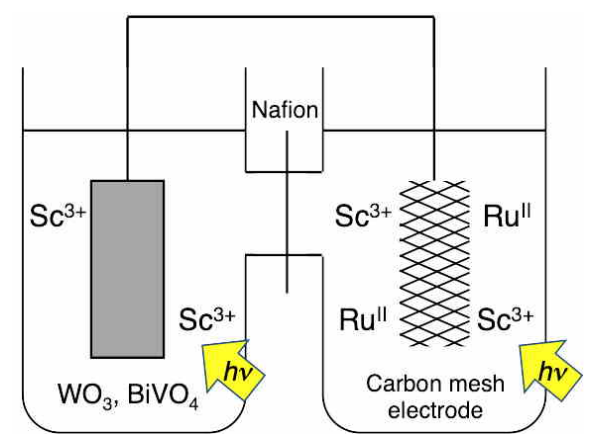

Fig. 2. A two-compartment cell employed for photocatalytic $\mathrm{H}_{2} \mathrm{O}_{2}$ production by combining the photocatalytic $\mathrm{H}_{2} \mathrm{O}$ oxidation and the photocatalytic $2 \mathrm{e}^{-} / 2 \mathrm{H}^{+} \mathrm{O}_{2}$ reduction under visible light illumination. Reproduced from Ref. [69] with permission from Royal Society of Chemistry (Copyright 2016).

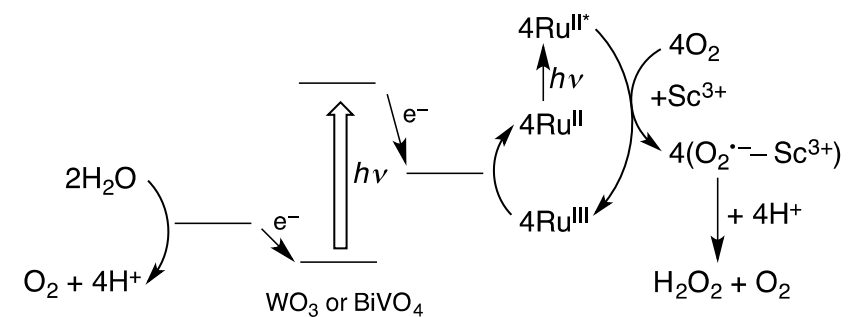

Scheme 3. Photocatalytic water oxidation by $\mathrm{O}_{2}$ to $\mathrm{H}_{2} \mathrm{O}_{2}$ by double photoexcitation. Reproduced from Ref. [69] with permission from Royal Society of Chemistry (Copyright 2016).

where $\mathrm{WO}_{3}$ or $\mathrm{BiVO}_{4}$ was employed as a photoanode for the photocatalytic $\mathrm{H}_{2} \mathrm{O}$ oxidation [70-73] and a carbon mesh cathode was used for the $2 \mathrm{e}^{-} / 2 \mathrm{H}^{+} \mathrm{O}_{2}$ reduction to $\mathrm{H}_{2} \mathrm{O}_{2}$ with a $\mathrm{Ru}$ complex [69]. The best performance was obtained when $\left[\mathrm{Ru}^{\mathrm{II}}\left((\mathrm{MeO})_{2} \text { bpy }\right)_{3}\right]^{2+}\left((\mathrm{MeO})_{2}\right.$ bpy $=4,4$ '-dimethoxy-2,2'-bipyridine) was used as a photocatalyst for the $2 \mathrm{e}^{-} / 2 \mathrm{H}^{+} \mathrm{O}_{2}$ reduction in an $\mathrm{O}_{2}$-saturated $\mathrm{H}_{2} \mathrm{O}$ containing $\mathrm{Sc}^{\mathrm{III}}\left(\mathrm{NO}_{3}\right)_{3}(0.10 \mathrm{M}) \mathrm{em}$ ploying the carbon mesh cathode and the $\mathrm{BiVO}_{4}$ photoanode for the photocatalytic $\mathrm{H}_{2} \mathrm{O}_{2}$ production by the $\mathrm{H}_{2} \mathrm{O}$ oxidation by $\mathrm{O}_{2}$ [69].

The mechanism of visible-light-driven $\mathrm{H}_{2} \mathrm{O}_{2}$ production by the catalytic $\mathrm{H}_{2} \mathrm{O}$ oxidation by $\mathrm{O}_{2}$ in the two-compartment cell is shown in Scheme 3 [69], where ET from photoexcited state of $\mathrm{Ru}(\mathrm{II})$ complex ([Ru' $\left.\left.{ }^{\mathrm{II}}\left((\mathrm{MeO})_{2} \mathrm{bpy}\right)_{3}\right]^{2+*}\right)$ to $\mathrm{O}_{2}$ with $\mathrm{Sc}^{3+}$ occurs to produce $\mathrm{Ru}(\mathrm{III})$ complex and $\mathrm{O}_{2}{ }^{--}-\mathrm{Sc}^{3+}$ species [62-64] that disproportionates with $\mathrm{H}^{+}$to produce $\mathrm{H}_{2} \mathrm{O}_{2}$ in competition of back ET from $\mathrm{O}_{2}{ }^{--}-\mathrm{Sc}^{3+}$ species to $\mathrm{Ru}(\mathrm{III})$ complex [50]. The photoexcitation of $\mathrm{BiVO}_{4}$ results in generation of holes and electrons, which oxidize $\mathrm{H}_{2} \mathrm{O}$ to $\mathrm{O}_{2}$ and reduce $\mathrm{Ru}(\mathrm{III})$ to $\mathrm{Ru}(\mathrm{II})$, respectively [69].

The solar energy conversion efficiency in the solar-light-driven $\mathrm{H}_{2} \mathrm{O}_{2}$ production by oxidation of $\mathrm{H}_{2} \mathrm{O}$ by $\mathrm{O}_{2}$ using a two-compartment cell was much improved by employing monoclinic bismuth vanadate $\left(\mathrm{BiVO}_{4}\right)$, which was modified with metal oxide(hydroxide) $(\mathrm{M}=\mathrm{O}(\mathrm{OH}), \mathrm{M}=\mathrm{Fe}, \mathrm{Ni})$ as a photoanode [74-76] and a cobalt chlorin complex adsorbed on carbon paper $\left(\mathrm{Co}^{\mathrm{II}}(\mathrm{Ch}) / \mathrm{CP}\right)$ as an efficient and selective catalyst for the $2 \mathrm{e}^{-} / 2 \mathrm{H}^{+}$reduction of $\mathrm{O}_{2}[77,78]$ (Scheme 4) [79]. The best solar-to- $\mathrm{H}_{2} \mathrm{O}_{2}$ energy conversion efficiency was obtained as $6.6 \%$ and $0.89 \%$ under 0.05 sun and 1 sun irradiation,

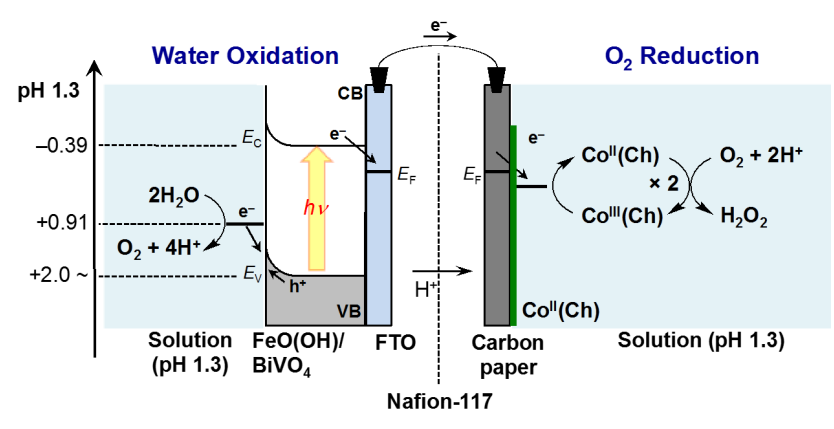

Scheme 4. Solar-light-driven $\mathrm{H}_{2} \mathrm{O}_{2}$ production with $\mathrm{FeO}(\mathrm{OH}) /$ $\mathrm{BiVO}_{4} / \mathrm{FTO}$ photoanode and $\mathrm{Co}^{\mathrm{II}}(\mathrm{Ch}) / \mathrm{CP}$ cathode in water or seawater under simulated 1 sun (AM 1.5G) irradiation. Reproduced from Ref. [79 with permission from American Chemical Society (Copyright 2016). 
respectively [79]. These values are much larger than that of swichgrass $(0.2 \%)$, which has been considered more recently as a biomass crop for ethanol and butanol (i.e., biomass fuel) [80].

Due to the global shortage of clean fresh water around the world, it is highly desirable to use seawater instead of pure water for solar-light-driven $\mathrm{H}_{2} \mathrm{O}_{2}$ production as a solar fuel, because seawater is the earth's richest water source. More efficient solar-light-driven production of $\mathrm{H}_{2} \mathrm{O}_{2}$ by the $\mathrm{H}_{2} \mathrm{O}$ oxidation by $\mathrm{O}_{2}$ was made possible by using seawater rather than pure water and $\mathrm{O}_{2}$ in the air with use of a two-compartment cell composed of $m$ - $\mathrm{WO}_{3} / \mathrm{FTO}$ photoanode and $\mathrm{Co}^{\mathrm{II}}(\mathrm{Ch}) / \mathrm{CP}$ cathode [81]. The rate of photocatalytic $\mathrm{H}_{2} \mathrm{O}_{2}$ production in seawater was markedly enhanced as compared with that in pure water. After $24 \mathrm{~h}$ simulated solar-light irradiation, the concentration of $\mathrm{H}_{2} \mathrm{O}_{2}$ produced in seawater increased up to 48 $\mathrm{mM}$, which could be directly used to operate an $\mathrm{H}_{2} \mathrm{O}_{2}$ fuel cell [81]. The virtually the same enhancement of solar-light-driven $\mathrm{H}_{2} \mathrm{O}_{2}$ production was observed using an $\mathrm{NaCl}$ solution, in which the concentration of $\mathrm{Cl}^{-}$was the same as that in the seawater [81]. The oxidation of $\mathrm{Cl}^{-}$rather than $\mathrm{H}_{2} \mathrm{O}$ by photogenerated hole upon photoexcitation of $\mathrm{WO}_{3}$ occurred to produce chlorine $\left(\mathrm{Cl}_{2}\right)$, which was converted to $\mathrm{HClO}$ depending on the $\mathrm{pH}$ of the solution [82]. $\mathrm{HClO}$ decomposed to produce $\mathrm{O}_{2}$ and $\mathrm{Cl}^{-}$under simulated solar-light irradiation [83]. Thus, the solar-light-driven water oxidation is accelerated by $\mathrm{Cl}^{-}$[81]. The solar energy conversion efficiency for the solar-light-driven $\mathrm{H}_{2} \mathrm{O}_{2}$ production in seawater was determined to be $0.55 \%$ under simulated 1 sun illumination [81].

$\mathrm{TiO}_{2}$ was reported to photocatalyze the production of $\mathrm{H}_{2} \mathrm{O}_{2}$ by $\mathrm{Au} \mathrm{NP}$ loading to yield $\mathrm{H}_{2} \mathrm{O}_{2}$ on a $10 \mathrm{mM}$ level [84]. $\mathrm{Au} / \mathrm{TiO}_{2}$ exhibited an efficient photocatalytic activity to attain the quantum yield ( $\Phi=$ molecules produced/incident photons) of $13 \%$ at the light wavelength $(\lambda=355 \pm 23 \mathrm{~nm})$ [84]. However, $4 \%$ ethanol was necessary as a hole-scavenger for the photodriven production of $\mathrm{H}_{2} \mathrm{O}_{2}$ to proceed [84]. Aliphatic alcohols are frequently used as hole-scavengers for the photocatalytic $\mathrm{H}_{2} \mathrm{O}_{2}$ production by the $2 \mathrm{e}^{-} / 2 \mathrm{H}^{+} \mathrm{O}_{2}$ reduction [85-88]. Graphitic carbon nitride (GCN), a metal-free polymeric semiconductor with a graphitic stacking structure of melem sheets also promotes selective $2 \mathrm{e}^{-} / 2 \mathrm{H}^{+} \mathrm{O}_{2}$ reduction with ethanol to produce $\mathrm{H}_{2} \mathrm{O}_{2}$ [89-91]. However, the $\mathrm{g}-\mathrm{C}_{3} \mathrm{~N}_{4}$ catalyst is not capable of photocatalyzing $\mathrm{H}_{2} \mathrm{O}_{2}$ production by the water oxidation by $\mathrm{O}_{2}$
[92], because the top of the valence band (VB) lies at approximately $1.4 \mathrm{~V}$ vs. NHE (normal hydrogen electrode) at pH 7 [93], which is insufficient for water oxidation (ca. $0.8 \mathrm{~V}$ ) [94,95].

Incorporating aromatic diimides into graphitic carbon nitrides $\left(\mathrm{g}-\mathrm{C}_{3} \mathrm{~N}_{4}\right)$ results in positive shifts of the oxidation and reduction potentials due to their high electron affinity [96]. Thus, incorporation of an electron deficient pyromellitic diimide (PDI) unit into the $\mathrm{g}-\mathrm{C}_{3} \mathrm{~N}_{4}$ network by thermal condensation (Scheme 5(a)) made it possible to act as a photocatalyst for $\mathrm{H}_{2} \mathrm{O}_{2}$ production by $\mathrm{H}_{2} \mathrm{O}$ oxidation by $\mathrm{O}_{2}$ without hole scavenger $[97,98]$. The g- $\mathrm{C}_{3} \mathrm{~N}_{4} / \mathrm{PDI}$ catalyst contains an electronic band structure capable of oxidizing $\mathrm{H}_{2} \mathrm{O}$ and reducing $\mathrm{O}_{2}$ as well $[97,98]$. Photoexcitation of the g- $\mathrm{C}_{3} \mathrm{~N}_{4} / \mathrm{PDI}$ catalyst at $\lambda<$ $470 \mathrm{~nm}$ (A in Scheme 5(c)) results in formation of hole $\left(\mathrm{h}^{+}\right)$and electron $\left(\mathrm{e}^{-}\right)$pairs at 2,6- and 1,4-positions on the melem unit, respectively ( $\mathrm{B}$ in Scheme 5(c)). The hole oxidizes $\mathrm{H}_{2} \mathrm{O}$, whereas the electron reduces $\mathrm{O}_{2}$ to produce a superoxo radical $(\mathrm{C}$ in Scheme 5(c)). Rapid reduction of the radical by another $\mathrm{e}^{-}$at the para position produces 1,4-endoperoxide species (D in Scheme 5 (c)), which is readily transformed to $\mathrm{H}_{2} \mathrm{O}_{2}$ by the reaction with $\mathrm{H}^{+}$(Scheme 5(c)) $[97,98]$. The efficient formation of the endoperoxide species suppresses the $\mathrm{e}^{-} / \mathrm{H}^{+}$or $4 \mathrm{e}^{-} / 4 \mathrm{H}^{+}$ $\mathrm{O}_{2}$ reduction, facilitating selective $2 \mathrm{e}^{-} / 2 \mathrm{H}^{+} \mathrm{O}_{2}$ reduction to produce $\mathrm{H}_{2} \mathrm{O}_{2}$ [98]. Moreover, no decomposition of $\mathrm{H}_{2} \mathrm{O}_{2}$ occurred in the presence of $\mathrm{g}-\mathrm{C}_{3} \mathrm{~N}_{4} / \mathrm{PDI}$ [98]. However, the amount of $\mathrm{H}_{2} \mathrm{O}_{2}$ produced after $48 \mathrm{~h}$ photoillumination was 30 $\mu \mathrm{mol}$ when the solar energy conversion efficiency was only $0.1 \%$ under simulated 1 sun irradiation, which should be much improved [97].

The solar energy conversion efficiency of photocatalytic $\mathrm{H}_{2} \mathrm{O}_{2}$ production with g- $\mathrm{C}_{3} \mathrm{~N}_{4} / \mathrm{PDI}$ was improved by hybridizing g- $\mathrm{C}_{3} \mathrm{~N}_{4}$ /PDI with reduced graphene oxide ( $\mathrm{rGO}$ ) by simple hydrothermal-calcination sequence to attain $0.20 \%$ under simulated 1 sun illumination [98]. Strong interaction between g- $\mathrm{C}_{3} \mathrm{~N}_{4} / \mathrm{PDI}$ and $\mathrm{rGO}$ promotes photoinduced charge separation of $\mathrm{h}^{+}$and $\mathrm{e}^{-}$[98]. The rGO acts as a trapping site for conduction band electron of the photoexcited g- $\mathrm{C}_{3} \mathrm{~N}_{4} / \mathrm{PDI}$ moiety as well as an active site promoting selective $2 \mathrm{e}^{-} / 2 \mathrm{H}^{+} \mathrm{O}_{2}$ reduction, thus promoting efficient $\mathrm{H}_{2} \mathrm{O}_{2}$ production under simulated solar-light illumination [98].

Charge transfer (CT) interaction between electron donor (D) and electron acceptor (A) units of copolymers results in formation of D-A couples with low HOMO (highest occupied (a)

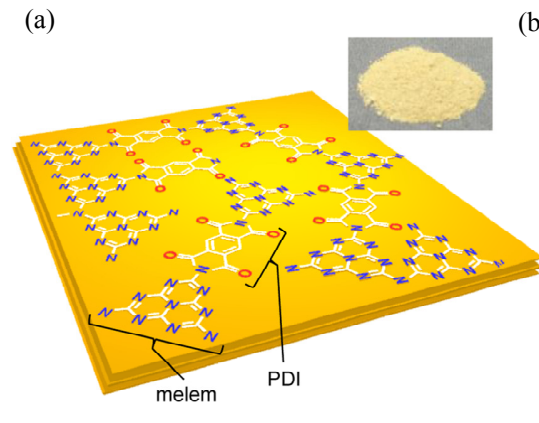

(b)

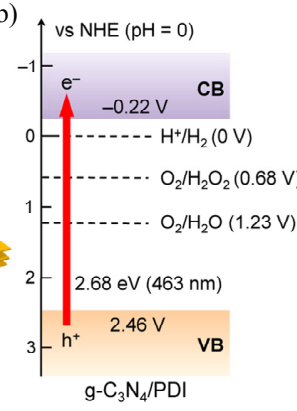

(c)

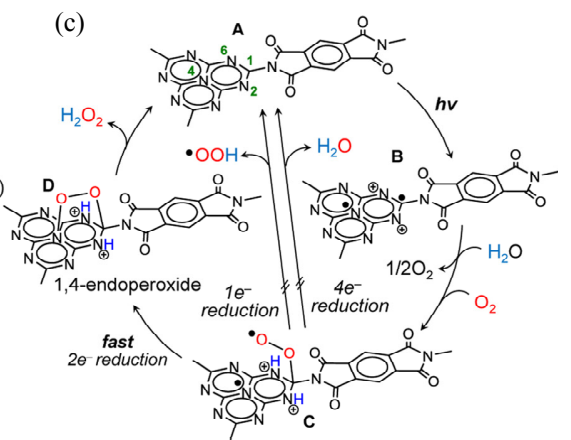

Scheme 5. (a) Three-dimensional structure; (b) Electronic band structure of g- $\mathrm{C}_{3} \mathrm{~N}_{4} / \mathrm{PDI}$ (containing $51 \%$ PDI unit); (c) Photocatalytic cycle for $\mathrm{H}_{2} \mathrm{O}_{2}$ production from $\mathrm{H}_{2} \mathrm{O}$ and $\mathrm{O}_{2}$ with g- $\mathrm{C}_{3} \mathrm{~N}_{4} / \mathrm{PDI}$. Reproduced from Ref. [98] with permission from American Chemical Society (Copyright 2016). 
molecular orbital) and LUMO (lowest unoccupied molecular orbital) gaps. The energy level hybridization by $\pi$-conjugation along the polymer chain and $\pi$-stacking between the chains forms a lower band-gap semiconductors with high conductivity to achieve efficient charge separation. High temperature and high pressure hydrothermal conditions were used to synthesize methylene-cross linked resorcinol-formaldehyde (RF) resins composed of a large number of quinoid forms of resorcinol acting as $A$, which are $\pi$-conjugated with inherent benzenoid forms of resorcinol as D [99]. The $\pi$-stacking of the benzenoid-quinoid D-A pairs leads to hybridization of the HOMO-LUMO levels, resulting in formation of semiconductors with low band-gaps. $\mathrm{RF}$ resins act as highly active D-A polymer photocatalysts to promote $\mathrm{H}_{2} \mathrm{O}_{2}$ production by oxidation of $\mathrm{H}_{2} \mathrm{O}$ by $\mathrm{O}_{2}$ using visible-light up to $700 \mathrm{~nm}$ [99]. Simulated solar-light illumination (1 sun) of the RF resin with $\mathrm{O}_{2}$ in $\mathrm{H}_{2} \mathrm{O}$ at barometric pressure produced $\mathrm{H}_{2} \mathrm{O}_{2}$ with the solar energy conversion efficiency of $0.5 \%$ [99].

In nature, water is oxidized in the photosystem II (PSII) to extract four electrons and four protons from two molecules of water, reducing the plastoquinone (PQ) in the quinone pool to produce plastoquinol $\left(\mathrm{PQH}_{2}\right)[100,101]$. The overall solar-light-driven $4 \mathrm{e}^{-} / 4 \mathrm{H}^{+} \mathrm{H}_{2} \mathrm{O}$ oxidation, accompanied by reduction of $\mathrm{PQ}$, is given by Eq. (1), where $\mathrm{PQ}$ is reduced by $\mathrm{H}_{2} \mathrm{O}$ to produce $\mathrm{O}_{2}$ and $\mathrm{PQH}_{2}[100,101]$.

$$
2 \mathrm{H}_{2} \mathrm{O}+2 \mathrm{PQ} \rightarrow \mathrm{O}_{2}+2 \mathrm{PQH}_{2}
$$

Photodriven $4 \mathrm{e}^{-} / 4 \mathrm{H}^{+} \mathrm{H}_{2} \mathrm{O}$ oxidation of by $p$-benzoquinone derivatives (X-Q), which is a potential functional mimic of PSII, was made possible by using a nonheme iron(II) complex, $\left[(\mathrm{N} 4 \mathrm{Py}) \mathrm{Fe}^{I I}\right]^{2+} \quad(\mathrm{N} 4 \mathrm{Py}=N, N$-bis$(2$-pyridylmethyl $)-N$-bis(2-pyridyl)methylamine) as a WOC [Eq. (2)] [102]. Photoirradiation of an MeCN solution containing 2,3-dichloro5,6-dicyano-p-benzoquinone (DDQ), [(N4Py)Fe $\left.{ }^{I I}\right]^{2+}$ and $\mathrm{H}_{2} \mathrm{O}$ using a Xe lamp resulted in $\mathrm{O}_{2}$ evolution with nearly $100 \%$ yield on the basis of the initial concentration of DDQ, while DDQ was reduced by $\mathrm{H}_{2} \mathrm{O}$ to produce $\mathrm{DDQH}_{2}$ [102]. The yield of $\mathrm{O}_{2}$ evolution was reduced due to the oxidation of $\mathrm{DDQH}_{2}$ by $\mathrm{O}_{2}$ to produce $\mathrm{H}_{2} \mathrm{O}_{2}$ with the regeneration of DDQ in long light irradiation time [Eq. (3)] [102]. Other $p$-benzoquinone derivatives, such as $p$-benzoquinone, $p$-chloranil, toluquinone and duroquionone, with $\left[(\mathrm{N} 4 \mathrm{Py}) \mathrm{Fe}^{\mathrm{II}}\right]^{2+}$ can also oxidize water to evolve $\mathrm{O}_{2}$ under photoillumination [102].

$$
\begin{aligned}
& 2 \mathrm{H}_{2} \mathrm{O}+2 \mathrm{X}-\mathrm{Q} \rightarrow \mathrm{O}_{2}+2 \mathrm{PQH}_{2} \\
& \mathrm{DDQH}_{2}+\mathrm{O}_{2} \rightarrow \mathrm{DDQ}+\mathrm{H}_{2} \mathrm{O}_{2}
\end{aligned}
$$

The catalytic mechanism of the photodriven $\mathrm{H}_{2} \mathrm{O}$ oxidation by $\mathrm{X}-\mathrm{Q}$ with $\left[(\mathrm{N} 4 \mathrm{Py}) \mathrm{Fe}^{\mathrm{II}}\right]^{2+}$ to evolve $\mathrm{O}_{2}$ is shown in Scheme 6, where DDQ is employed as an oxidant [102]. Photoexcitation of DDQ results in formation of the triplet excited state ( $\left.{ }^{3} \mathrm{DDQ}^{*}\right)$ via intersystem crossing from the singlet excited state ( $\left.{ }^{1} \mathrm{DDQ}^{*}\right)$ $[103,104]$. Fe(II) species is oxidized by ${ }^{3} \mathrm{DDQ}^{*}$ via ET to produce Fe(III) and DDQ ${ }^{--}$species. The rate constant was determined by laser-induced transient absorption measurements to be $1.0 \times$ $10^{10} \mathrm{M}^{-1} \mathrm{~s}^{-1}$, which is close to the diffusion-limited rate constant at $298 \mathrm{~K}$. Fe(III) species produced by the photoinduced ET reacts with $\mathrm{H}_{2} \mathrm{O}$ to generate the iron(III)-hydroxo (Fe $\left.{ }^{\mathrm{III}}-\mathrm{OH}\right)$ complex and $\mathrm{H}^{+}$, whereas DDQ*- is protonated to form DDQH (pathway a in Scheme 6). Iron(III)-hydroxo complex is further

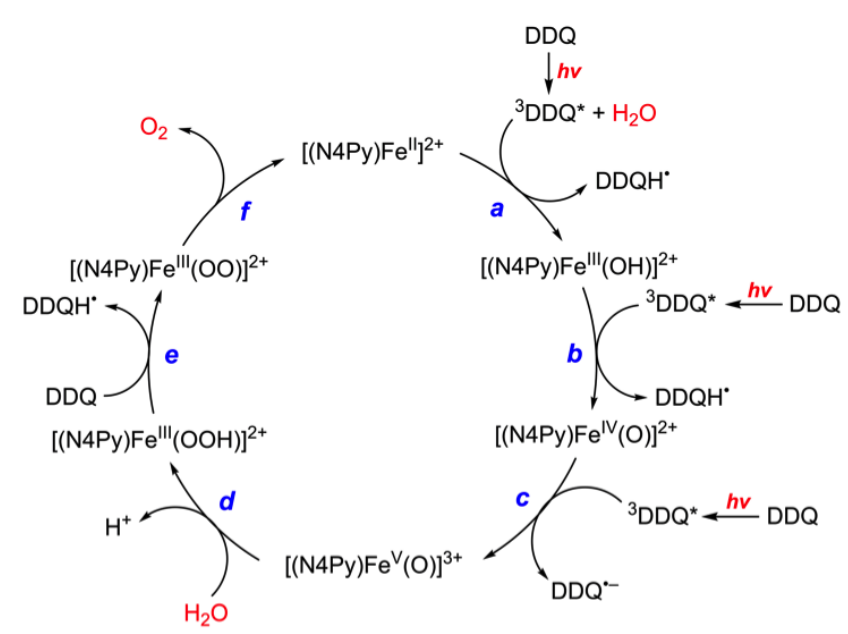

Scheme 6. Proposed mechanism of the photocatalytic oxidation of $\mathrm{H}_{2} \mathrm{O}$ by DDQ with [(N4Py)Ferl] ${ }^{2+}$ to evolve $\mathrm{O}_{2}$. Reproduced from Ref. [102] with permission from American Chemical Society (Copyright 2019).

oxidized by ${ }^{3} \mathrm{DDQ}^{*}$ via ET to generate the iron(IV)-oxo [Fe $\left.{ }^{\mathrm{IV}}(\mathrm{O})\right]$ complex and DDQH• (pathway b in Scheme 6) [102]. The formation of iron(IV)-oxo was detected by the laser-induced transient absorption measurements $\left(\lambda_{\max }=690 \mathrm{~nm}\right)$ [102]. Then, ET from $\mathrm{Fe}^{\mathrm{IV}}(\mathrm{O})$ to ${ }^{3} \mathrm{DDQ}^{*}$ occurs to generate the iron(V)-oxo $\left[\mathrm{FeV}^{\mathrm{V}}(\mathrm{O})\right]$ complex and DDQ*-. The rate constant of the photoinduced ET was determined to be $9.4 \times 10^{9} \mathrm{M}^{-1} \mathrm{~s}^{-1}$, which is also close to the diffusion-limited rate constant at $298 \mathrm{~K}$ (pathway c in Scheme 6) [102]. A nucleophilic attack of $\mathrm{H}_{2} \mathrm{O}$ to $\mathrm{FeV}(\mathrm{O})$ generates the iron(III)-hydroperoxo [FeIII $(\mathrm{OOH})]$ complex and $\mathrm{H}^{+}$ (pathway d in Scheme 6) [102]. Iron(III)-hydroperoxo species is oxidized thermally by DDQ to produce the iron(III)-superoxo $\left[\mathrm{Fe}^{\mathrm{III}}\left(\mathrm{O}_{2}{ }^{-}\right)\right]$complex and $\mathrm{DDQH} \cdot$ species (pathway e in Scheme 6), followed by $\mathrm{O}_{2}$ release to regenerate iron(II) complex (pathway $\mathrm{f}$ in Scheme 6) [102]. It was confirmed that iron(III)-hydroperoxo was oxidized by DDQ thermally to evolve $\mathrm{O}_{2}$, when iron(III)-hydroperoxo complex was independently prepared by the oxidation of iron(II) complex by $\mathrm{H}_{2} \mathrm{O}_{2}$ [102] DDQ can be replaced by other $p$-benzoquinone derivatives (X-Q) to achieve photocatalytic oxidation of $\mathrm{H}_{2} \mathrm{O}$ by X-Q with iron(II) complex to evolve $\mathrm{O}_{2}$ [102]. The combination of the photocatalytic $4 \mathrm{e}^{-} / 4 \mathrm{H}^{+} \mathrm{H}_{2} \mathrm{O}$ oxidation by X-Q with iron(II) complex (i.e., [(N4Py)Fe $\left.{ }^{I I}\right]^{2+}$ ) and $2 \mathrm{e}^{-} / 2 \mathrm{H}^{+} \mathrm{O}_{2}$ reduction by $\mathrm{X}-\mathrm{QH}_{2}$ would enhance the production of $\mathrm{H}_{2} \mathrm{O}_{2}$ by oxidation of $\mathrm{H}_{2} \mathrm{O}$ by $\mathrm{O}_{2}$.

\section{3. $2 \mathrm{e}^{-} / 2 \mathrm{H}^{+}$Oxidation of $\mathrm{H}_{2} \mathrm{O}$}

In addition to the $4 \mathrm{e}^{-} / 4 \mathrm{H}^{+} \mathrm{H}_{2} \mathrm{O}$ oxidation to evolve $\mathrm{O}_{2}$ (the reverse reaction of the $4 \mathrm{e}^{-} / 4 \mathrm{H}^{+} \mathrm{O}_{2}$ reduction), the $2 \mathrm{e}^{-} / 2 \mathrm{H}^{+} \mathrm{H}_{2} \mathrm{O}$ oxidation affords $\mathrm{H}_{2} \mathrm{O}_{2}$ [Eq. (4)] [105,106]. The combination of the $2 \mathrm{e}^{-} / 2 \mathrm{H}^{+} \mathrm{H}_{2} \mathrm{O}$ oxidation with the $2 \mathrm{e}^{-}$reduction of $2 \mathrm{H}^{+}$[Eq. (5)] results in water splitting to produce $\mathrm{H}_{2} \mathrm{O}_{2}$ and $\mathrm{H}_{2}$ [Eq. (6)] [106].

$$
\begin{gathered}
2 \mathrm{H}_{2} \mathrm{O}-2 \mathrm{e}^{-} \rightarrow \mathrm{H}_{2} \mathrm{O}_{2}+2 \mathrm{H}^{+} \quad E_{1 / 2}=1.77 \mathrm{~V} \text { vs. RHE } \\
2 \mathrm{H}^{+}+2 \mathrm{e}^{-} \rightarrow \mathrm{H}_{2} \\
2 \mathrm{H}_{2} \mathrm{O} \rightarrow \mathrm{H}_{2} \mathrm{O}_{2}+\mathrm{H}_{2}
\end{gathered}
$$




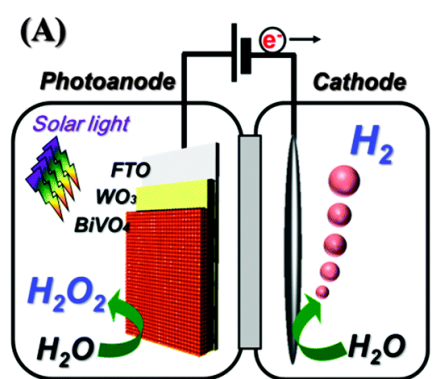

(B) applied voltage (>ca. $0.4 \mathrm{~V})$

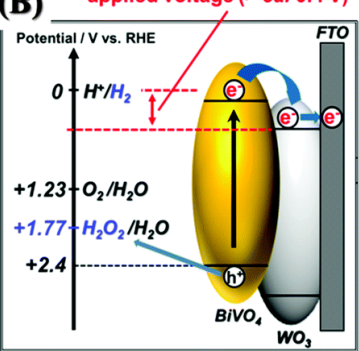

Fig. 3. (A) Photoanode and cathode for photoelectrochemical water splitting to $\mathrm{H}_{2} \mathrm{O}_{2}$ and $\mathrm{H}_{2}$. (B) Energy diagram of photoelectrocatalytic production of $\mathrm{H}_{2} \mathrm{O}_{2}$ and $\mathrm{H}_{2}$ using a $\mathrm{WO}_{3} / \mathrm{BiVO}_{4}$ photoanode under solar-light illumination. Reproduced from Ref. [110] with permission from Royal Society of Chemistry (Copyright 2016).

The photoelectrochemical water splitting to $\mathrm{H}_{2} \mathrm{O}_{2}$ and $\mathrm{H}_{2}$ has been achieved with use of a $\mathrm{WO}_{3} / \mathrm{BiVO}_{4}$ photoanode [107-109] under simulated solar-light illumination by applying potential much lower than that applied to the electrode in electrolysis (ca. > 0.4 V) (Fig. 3) [110]. $\mathrm{H}_{2} \mathrm{O}_{2}$ was produced only in the presence of $\mathrm{KHCO}_{3}$ in $\mathrm{H}_{2} \mathrm{O}$ and the maximum selectivity $\left(\eta\left(\mathrm{H}_{2} \mathrm{O}_{2}\right)\right)$ for $\mathrm{H}_{2} \mathrm{O}_{2}$ production reached $54 \%$ in the presence of a high concentration $(2.0 \mathrm{M})$ of $\mathrm{HCO}_{3}{ }^{-}$in $\mathrm{H}_{2} \mathrm{O}$ at $5{ }^{\circ} \mathrm{C}$, and the $\mathrm{H}_{2} \mathrm{O}_{2}$ concentration produced was $2.0 \mathrm{mM}$ [110]. When $\mathrm{KHCO}_{3}$ was replaced by other electrolytes, $\mathrm{H}_{2} \mathrm{O}_{2}$ was hardly produced [110]. Although the role of $\mathrm{KHCO}_{3}$ for the photoelectrocatalytic production of $\mathrm{H}_{2} \mathrm{O}_{2}$ has yet to be well clarified, $\mathrm{HCO}_{3}{ }^{-}$oxidation in the holes of $\mathrm{BiVO}_{4}$ may produce $\mathrm{HCO}_{4}{ }^{-}$and $\mathrm{C}_{2} \mathrm{O}_{6}{ }^{2-}$, which act as an effective catalyst for the $2 \mathrm{e}^{-} / 2 \mathrm{H}^{+} \mathrm{H}_{2} \mathrm{O}$ oxidation [107]. The Faraday efficiency of photoelectrocatalytic production of $\mathrm{H}_{2} \mathrm{O}_{2}$ and $\mathrm{O}_{2}$ reached $100 \%$ in the anode reaction, indicating that the oxidized products of $\mathrm{H}_{2} \mathrm{O}$ were only $\mathrm{H}_{2} \mathrm{O}_{2}$ and $\mathrm{O}_{2}$ [110]. The maximum $\eta\left(\mathrm{H}_{2} \mathrm{O}_{2}\right)$ value was improved to $73 \%$ by using an Sb-modified anode containing mixed metal oxides such as $\mathrm{CuSbO}_{x} /$ FTO and $\operatorname{InSbO}_{x} /$ FTO [111]. The TON based on the number of loaded metal oxides exceeded 82,000 [111]. The $\mathrm{H}_{2}$ gas was evolved as a reductive product of protons in Eq. (2) on the Pt cathode with $100 \%$ Faraday efficiency [110].

$\mathrm{Bi}_{2} \mathrm{WO}_{6}$ is also used as a suitable electrode for $\mathrm{H}_{2} \mathrm{O}_{2}$ production by $2 \mathrm{e}^{-} / 2 \mathrm{H}^{+}$oxidation of $\mathrm{H}_{2} \mathrm{O}$. The rate of $\mathrm{H}_{2} \mathrm{O}_{2}$ production was optimized by Mo-doping and enlarged specific surface area [110]. The $\mathrm{FTO} / \mathrm{Bi}_{2} \mathrm{WO}_{6}:$ Mo electrode afforded the maximum Faraday efficiency of $79 \%$ at $3.2 \mathrm{~V}$ (vs. RHE), exhibiting good durability at least for $6 \mathrm{~h}$ electrolysis [110].

Combination of a $\mathrm{WO}_{3} / \mathrm{BiVO}_{4}$ photoanode with a $\mathrm{HCO}_{3}{ }^{-}$ electrolyte for the $2 \mathrm{e}^{-} / 2 \mathrm{H}^{+}$oxidation of $\mathrm{H}_{2} \mathrm{O}$ and an $\mathrm{Au}$ cathode for the $2 \mathrm{e}^{-} / 2 \mathrm{H}^{+}$reduction of $\mathrm{O}_{2}$ resulted in solar-light-driven production of $\mathrm{H}_{2} \mathrm{O}_{2}\left(\eta_{\text {anode }}\left(\mathrm{H}_{2} \mathrm{O}_{2}\right) \approx 50 \%\right.$ and $\eta_{\text {cathode }}\left(\mathrm{H}_{2} \mathrm{O}_{2}\right) \approx$ $90 \%$ ) without applied potential between the photoanode and cathode under simulated solar-light illumination when an Au-supported porous $\mathrm{BiVO}_{4}$ sheet (Fig. 4) was employed as a photocatalyst [111]. A composite electrode $\left(\mathrm{WO}_{3} / \mathrm{BiVO}_{4}+\mathrm{Au}\right)$, which was supported by both porous $\mathrm{WO}_{3} / \mathrm{BiVO}_{4}$ and $\mathrm{Au}$ on a single FTO substrate, was prepared to achieve simultaneous $\mathrm{H}_{2} \mathrm{O}_{2}$ production by the $2 \mathrm{e}^{-} / 2 \mathrm{H}^{+} \mathrm{H}_{2} \mathrm{O}$ oxidation combined with the $2 \mathrm{e}^{-} / 2 \mathrm{H}^{+} \mathrm{O}_{2}$ reduction on a single photoelectrode substrate

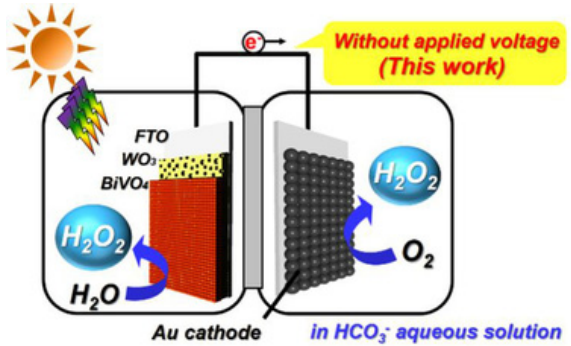

Fig. 4. A photoelectrode system for production of $\mathrm{H}_{2} \mathrm{O}_{2}$ via the $2 \mathrm{e}^{-} / 2 \mathrm{H}^{+}$ $\mathrm{H}_{2} \mathrm{O}$ oxidation on a $\mathrm{WO}_{3} / \mathrm{BiVO}_{4}$ photoanode combined with the $2 \mathrm{e}^{-} / 2 \mathrm{H}^{+}$ $\mathrm{O}_{2}$ reduction on an $\mathrm{Au}$ cathode under solar-light illumination. Reproduced from Ref. [111] with permission from John WILEY and Sons (Copyright 2017).

(photocatalyst sheet) without separating anode and cathode solutions under simulated solar-light illumination (Fig. 5(A) (C)) [111]. The $\mathrm{WO}_{3} / \mathrm{BiVO}_{4}$ electrode was obtained by a two-step process using the same procedure on half of an FTO substrate and the Au sheet was prepared by the same sputtering method on another half of an FTO substrate (Fig. 5(A) and 5(B)) [111]. $\mathrm{H}_{2} \mathrm{O}_{2}$ was produced under photoirradiation even on this composite electrode containing $\mathrm{WO}_{3} / \mathrm{BiVO}_{4}$ and $\mathrm{Au}$ on a single FTO substrate in an aqueous solution containing $\mathrm{KHCO}_{3}$
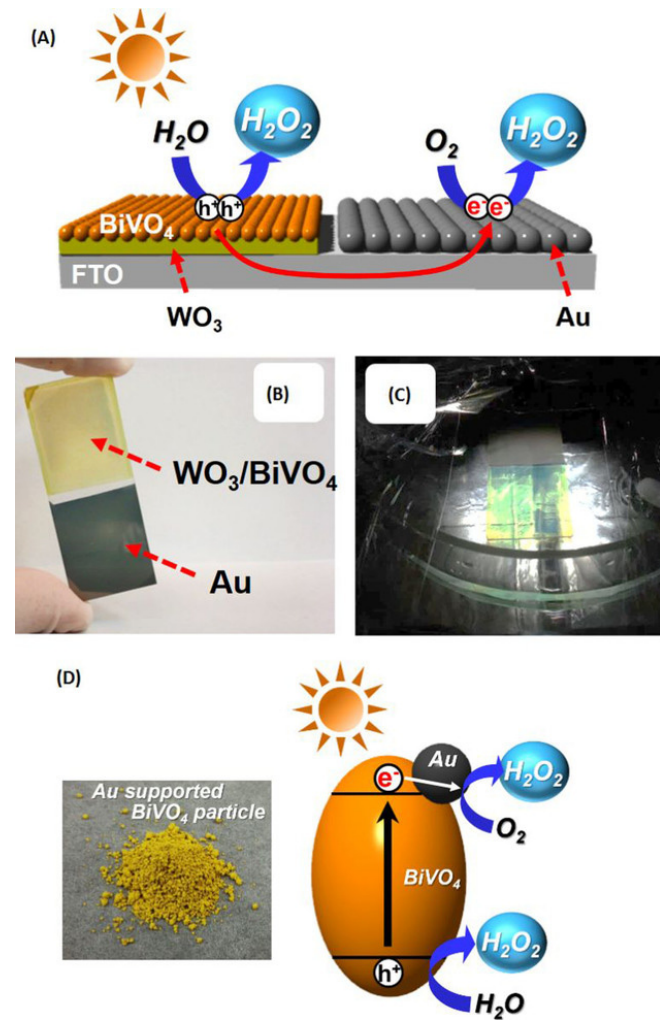

Fig. 5. (A) Reaction diagram of photocatalytic production of $\mathrm{H}_{2} \mathrm{O}_{2}$; (B) Composite electrode supported $\mathrm{WO}_{3} / \mathrm{BiVO}_{4}$ and $\mathrm{Au}$ on a single FTO substrate; (C) Solar-light-driven production of $\mathrm{H}_{2} \mathrm{O}_{2}$ on the composite electrode under simulated solar-light illumination in $\mathrm{H}_{2} \mathrm{O}$ containing $\mathrm{KHCO}_{3}(2.0 \mathrm{M})$ at below $5{ }^{\circ} \mathrm{C}$ under $\mathrm{O}_{2}$ and $\mathrm{CO}_{2}$ bubbling with use of a petri dish as a cell; (D) Reaction diagram of photocatalytic production of $\mathrm{H}_{2} \mathrm{O}_{2}$ on an $\mathrm{Au}$-supported $\mathrm{BiVO}_{4}$ powder in $\mathrm{H}_{2} \mathrm{O}$ containing $\mathrm{KHCO}_{3}$ (2.0 M) under $\mathrm{O}_{2}$ and $\mathrm{CO}_{2}$ bubbling. Reproduced from Ref. [111] with permission from John WILEY and Sons (Copyright 2017). 
(2.0 M). The concentration of $\mathrm{H}_{2} \mathrm{O}_{2}$ reached approximately 130 $\mu \mathrm{M}$ after 60 min light photoirradiation [111]. The realization of $\mathrm{H}_{2} \mathrm{O}_{2}$ production by using $\mathrm{WO}_{3} / \mathrm{BiVO}_{4}$ with an $\mathrm{Au}$ electrode under solar-light illumination suggests that an ultimate simple system is made possible by oxidative and reductive $\mathrm{H}_{2} \mathrm{O}_{2}$ generation by using $\mathrm{BiVO}_{4}$ photocatalyst powder with $\mathrm{Au}$ particles as a cocatalyst (Fig. 5(D)) [111]. In fact, $\mathrm{H}_{2} \mathrm{O}_{2}$ (ca. $220 \mu \mathrm{M}$ for 60 min) was produced by using $\mathrm{Au}$-supported $\mathrm{BiVO}_{4}$ photocatalyst powder suspended in $\mathrm{H}_{2} \mathrm{O}$ containing $\mathrm{KHCO}_{3}(2.0 \mathrm{M})$ under simulated solar-light illumination [111]. A $\quad \mathrm{BiVO}_{4} / \mathrm{WO}_{3}$ photoelectrode was modified with $\mathrm{Al}_{2} \mathrm{O}_{3}$ by a chemical vapor deposition (CVD) method and solar-light-driven production of $\mathrm{H}_{2} \mathrm{O}_{2}$ in $\mathrm{H}_{2} \mathrm{O}$ containing $\mathrm{KHCO}_{3}(2.0 \mathrm{M})$ was achieved by using the $\mathrm{Al}_{2} \mathrm{O}_{3} / \mathrm{BiVO}_{4} / \mathrm{WO}_{3}$ photoelectrode and a biomass-derived carbon cathode without applying any external bias potential to obtain Faraday efficiencies of $44 \%$ for the cathode and $60 \%$ for photoelectrode [112].

\section{Hydrogen peroxide fuel cells}

Hydrogen peroxide obtained by the photocatalytic oxidation of water or seawater by $\mathrm{O}_{2}$ (vide supra) was used as a fuel in a one-compartment $\mathrm{H}_{2} \mathrm{O}_{2}$ fuel cell composed of a Prussian blue-structured polynuclear cyanide complex $\left(\mathrm{Fe}_{3}{ }_{3}\left[\mathrm{Co}^{\mathrm{III}}(\mathrm{CN})_{6}\right]_{2}\right)$ adsorbed on a carbon cloth (CP) cathode and a nickel mesh anode [17-20,113]. Such a membraneless one-compartment $\mathrm{H}_{2} \mathrm{O}_{2}$ fuel cell utilizes $\mathrm{H}_{2} \mathrm{O}_{2}$ for both oxidant and reductant to achieve a theoretical output potential of 1.09 $\mathrm{V}$ (Scheme 7), which is only slightly lower but comparable to that can be obtained from a hydrogen fuel cell (1.23 V) [15]. The reaction solution ( $\mathrm{pH}$ 1.3) containing $\mathrm{H}_{2} \mathrm{O}_{2}(52 \mathrm{mM})$ in the $\mathrm{Co}^{\mathrm{II}}(\mathrm{Ch}) / \mathrm{CP}$ cathode produced after photocatalytic $4 \mathrm{e}^{-} / 4 \mathrm{H}^{+} \mathrm{H}_{2} \mathrm{O}$ oxidation with the $\mathrm{FeO}(\mathrm{OH}) / \mathrm{BiVO}_{4} / \mathrm{FTO}$ photoanode and the $2 \mathrm{e}^{-} / 2 \mathrm{H}^{+} \mathrm{O}_{2}$ reduction with $\mathrm{Co}^{\mathrm{II}}(\mathrm{Ch}) / \mathrm{CP}$ cathode (Scheme 4 ) was transferred to an $\mathrm{H}_{2} \mathrm{O}_{2}$ fuel cell, which exhibited an open circuit potential and a maximum power density of $0.79 \mathrm{~V}$ and $2.0 \mathrm{~mW}$ $\mathrm{cm}^{-2}$, respectively (Fig. 6) [79]. The conversion of chemical energy to electric energy using $\mathrm{H}_{2} \mathrm{O}_{2}$ as a solar fuel was achieved to obtain the solar-to-electricity conversion efficiency of the total system as $3.3 \%$, because the energy conversion efficiency of the $\mathrm{H}_{2} \mathrm{O}_{2}$ fuel cell was $\sim 50 \%$ [79].

It is desired to replace a $\mathrm{Ni}$ anode used for one-compartment $\mathrm{H}_{2} \mathrm{O}_{2}$ fuel cells because $\mathrm{Ni}$ is vulnerable to $\mathrm{H}_{2} \mathrm{O}_{2}$. An anodic catalyst composed of carbon nanotubes (CNTs)

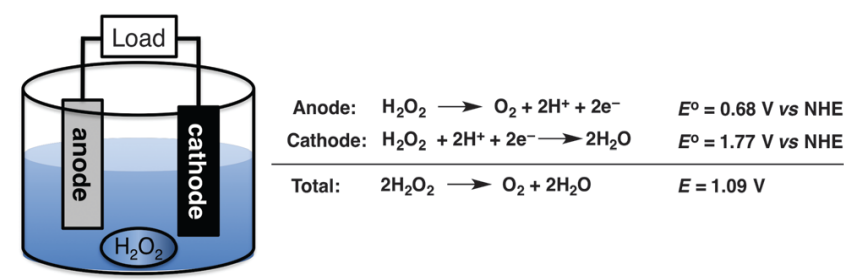

Scheme 7. A membraneless one-compartment $\mathrm{H}_{2} \mathrm{O}_{2}$ fuel cell in which the anode $\left(2 \mathrm{e}^{-} / 2 \mathrm{H}^{+} \mathrm{H}_{2} \mathrm{O}_{2}\right.$ oxidation $)$ and cathode $\left(2 \mathrm{e}^{-} / 2 \mathrm{H}^{+} \mathrm{H}_{2} \mathrm{O}_{2}\right.$ reduction) reactions afford the output potential of $1.09 \mathrm{~V}$. Reproduced from Ref. [113] with permission from Royal Society of Chemistry (Copyright 2015).

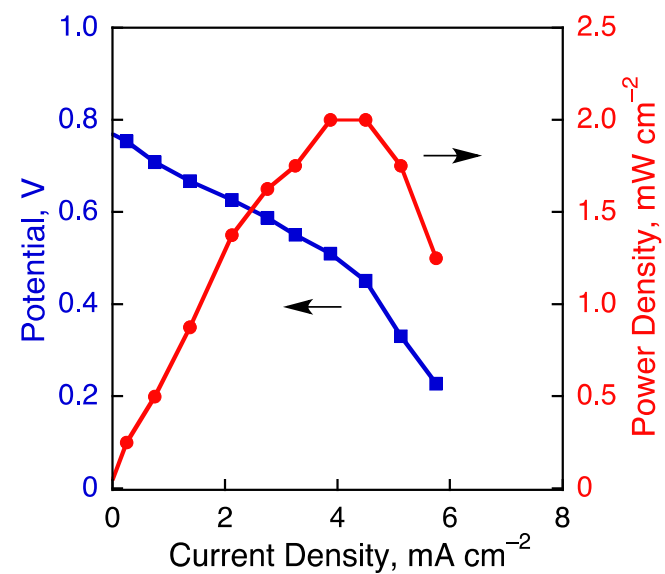

Fig. 6. Plots of $I-V$ (blue) and $I-P$ (red) of a one-compartment $\mathrm{H}_{2} \mathrm{O}_{2}$ fuel cell with a $\mathrm{Fe}_{3}{ }_{3}\left[\mathrm{Co}^{\mathrm{III}}(\mathrm{CN})_{6}\right]_{2} /$ carbon cloth cathode and a Ni mesh anode. Performance tests were carried out in a pH 1.3 aqueous solution, which was transferred from the $\mathrm{Co}^{\mathrm{II}}(\mathrm{Ch}) / \mathrm{CP}$ cathode cell of the two- compartment cells containing $52 \mathrm{mM}$ of $\mathrm{H}_{2} \mathrm{O}_{2}$ produced by photocatalytic $\mathrm{H}_{2} \mathrm{O}$ oxidation by $\mathrm{O}_{2}$ (see also Scheme 4). Reproduced from Ref. [79] with permission from American Chemical Society (Copyright 2016).

and vitamin $\mathrm{B}_{12}\left(\mathrm{CNT} / \mathrm{VitB}_{12}\right)$ was reported to promote the $\mathrm{H}_{2} \mathrm{O}_{2}$ oxidation, improving the cell performance of a membraneless $\mathrm{H}_{2} \mathrm{O}_{2}$ fuel cell [114]. The open circuit voltage (OCV) and maximum power density of the $100 \mathrm{mM} \mathrm{H}_{2} \mathrm{O}_{2}$ fuel were

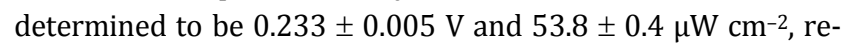
spectively [114].

A metal-free conducting polymer, poly(3,4-ethylenedioxythiophene (PEDOT), was utilized as a cathodic catalyst for the $2 \mathrm{e}^{-} / 2 \mathrm{H}^{+} \mathrm{H}_{2} \mathrm{O}_{2}$ reduction to $\mathrm{H}_{2} \mathrm{O}$ with a $\mathrm{Ni}$ anode to obtain open circuit potentials in the range of 0.5 to $0.6 \mathrm{~V}$ with power densities in the range of 0.20 to $0.30 \mathrm{~mW} \mathrm{~cm}^{-2}$ [115]. The $\mathrm{H}_{2} \mathrm{O}_{2}$ fuel cell performance would be improved by optimizing PEDOT formulations or by switching to other next generation conductive polymers capable of developing anodic catalysts that facilitate $\mathrm{H}_{2} \mathrm{O}_{2}$ oxidation, leading to a complete metal-free membraneless one-compartment $\mathrm{H}_{2} \mathrm{O}_{2}$ fuel cell [115].

A membraneless microfluidic fuel cell (MMFC) with a single stream in the cotton threads is shown in Fig. 7, where a capillary coupled with gravity forces is used to move the reactant solution transport through the cotton threads without any external pump [13]. The MMFC consists of a cover plate, Ni mesh adopted as an anode to catalyze $\mathrm{H}_{2} \mathrm{O}_{2}$ oxidation, and Prussian blue (PB)-coated CP employed as a cathode to catalyze $\mathrm{H}_{2} \mathrm{O}_{2}$ reduction [13]. The cover and supporting plates composed of poly(methyl methacrylate) (PMMA) are used to fix and support electrodes, respectively. Thirty cotton threads are placed in parallel on the electrodes to form a flow channel for the reactant. In this MMFC, fuel crossover or diffusion mixing between fuel and oxidant can be avoided [13]. The MMFC generated an open circuit potential of $0.66 \mathrm{~V}$ with a maximum power density of $5.5 \mathrm{~mW} \mathrm{~cm}$, which are larger than those of other $\mathrm{H}_{2} \mathrm{O}_{2}$ MMFCs reported previously [116-121]. The MMFC was applied to develop a self-powered $\mathrm{H}_{2} \mathrm{O}_{2}$ electrochemical sensor on the basis of the proposed fuel cell structure [13]. 


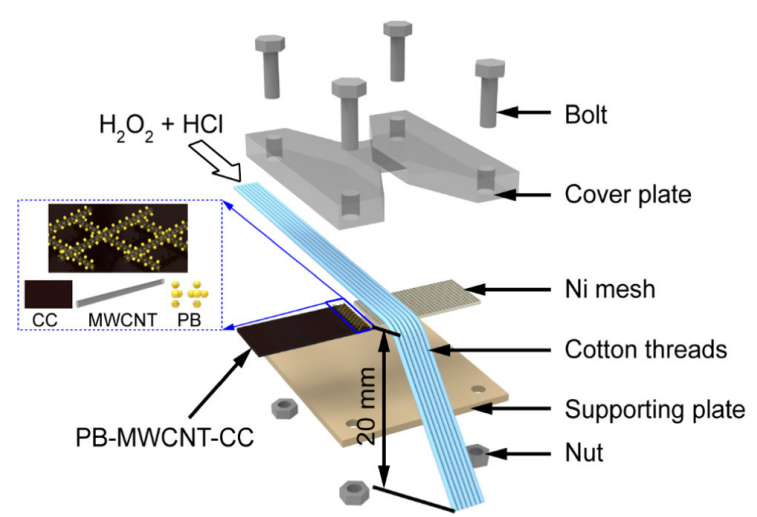

Fig. 7. Illustration of a $\mathrm{H}_{2} \mathrm{O}_{2}$ MMFC. Reproduced from Ref. [13] with permission from American Chemical Society (Copyright 2020).

\section{Oxidation of organic substrates with photogenerated $\mathrm{H}_{2} \mathrm{O}_{2}$}

Hydrogen peroxide has been widely used for selective oxidation of organic substrates with oxidation catalysts [7-14]. The rational development of a series of oxidation catalysts for direct $\mathrm{C}-\mathrm{H}$ or $\mathrm{C}-\mathrm{C}$ bond activation with $\mathrm{H}_{2} \mathrm{O}_{2}$ has now reached maturity for use in selective late-stage functionalization of organic compounds [122-128]. Because $\mathrm{H}_{2} \mathrm{O}_{2}$ can be produced from $\mathrm{H}_{2} \mathrm{O}$ as a reductant and $\mathrm{O}_{2}$ as an oxidant (vide supra), combination of photodriven production of $\mathrm{H}_{2} \mathrm{O}_{2}$ by oxidation of $\mathrm{H}_{2} \mathrm{O}$ by $\mathrm{O}_{2}$ with the thermal oxidation of organic substrates by $\mathrm{H}_{2} \mathrm{O}_{2}$ with a catalyst provides a cost effective method for selective photodriven oxidation of organic substrates using only $\mathrm{H}_{2} \mathrm{O}$ and $\mathrm{O}_{2}$ as an oxygen source and an oxidant, respectively.

Photocatalytic production of $\mathrm{H}_{2} \mathrm{O}_{2}$ by oxidation of $\mathrm{H}_{2} \mathrm{O}$ by $\mathrm{O}_{2}$ with $\left[\mathrm{Ru}^{\mathrm{II}}\left(4,7-\mathrm{Me}_{2} \text { phen }\right)_{3}\right]^{2+}$ as a photocatalyst and $\left[\left(\mathrm{Cp}^{*}\right) \mathrm{Co}^{\mathrm{III}}(\mathrm{bpy})\left(\mathrm{H}_{2} \mathrm{O}\right)\right]^{2+}$ as a water oxidation catalyst was combined with the catalytic hydroxylation of benzene with $\mathrm{H}_{2} \mathrm{O}_{2}$ using $\left[\left(\mathrm{Cp}^{*}\right) \mathrm{Co}^{\mathrm{III}}(\mathrm{bpy})\left(\mathrm{H}_{2} \mathrm{O}\right)\right]^{2+}$ that acts not only as a WOC but also as a benzene hydroxylation catalyst to yield phenol with TON > 500 (Scheme 8) [129]. This TON is much larger than those reported for photocatalytic hydroxylation of benzene with $\mathrm{O}_{2}$ using organic photocatalysts [130-132]. Photoexcitation of $\mathrm{Ru}$ (II) complex resulted in formation of $\mathrm{Ru}^{2+*}$ and ET from $\mathrm{Ru}^{2+*}$ to $\mathrm{O}_{2}$ in the presence of $\mathrm{Sc}^{\mathrm{III}}\left(\mathrm{NO}_{3}\right)_{3}$ to produce $\mathrm{Ru}(\mathrm{III})$ complex and $\mathrm{O}_{2}{ }^{\cdot-}-\mathrm{Sc}^{3+}$ species that disproportionates to produce $\mathrm{H}_{2} \mathrm{O}_{2}$ and $\mathrm{O}_{2}$ in the presence of $\mathrm{H}^{+}$(Scheme 8, pathways (b) and (c)) [129]. Ru(III) complex is used as an oxidant to oxidize water with $\left[\left(\mathrm{Cp}^{*}\right) \mathrm{Co}^{\mathrm{III}}(\mathrm{bpy})\left(\mathrm{H}_{2} \mathrm{O}\right)\right]^{2+}$ (Scheme 8, pathway (a)).

Phenol Production by benzene hydroxylation has also been achieved by combination of the catalytic benzene hydroxylation with $\mathrm{H}_{2} \mathrm{O}_{2}$ and photocatalytic $\mathrm{H}_{2} \mathrm{O}_{2}$ production by oxidation of $\mathrm{H}_{2} \mathrm{O}$ by $\mathrm{O}_{2}$ with use of a CN-bridged polynuclear $\mathrm{Fe}(\mathrm{II})-\mathrm{Ru}(\mathrm{II})$ complex $\left(\mathrm{Fe}^{\mathrm{II}} 2\left[\mathrm{Ru}^{\mathrm{II}}(\mathrm{CN})_{6}\right]\right)$, incorporated into mesoporous silica-alumina (sAl-MCM-41), Fe ${ }^{\mathrm{II}_{2}}\left[\mathrm{Ru}^{\mathrm{II}}(\mathrm{CN})_{6}\right] @$ sAl-MCM-41, acting as a triple functional catalyst for benzene hydroxylation catalyst, WOC and a photocatalyst for the $2 \mathrm{e}^{-} / 2 \mathrm{H}^{+} \mathrm{O}_{2}$ reduction to $\mathrm{H}_{2} \mathrm{O}_{2}$ [133]. The catalytic durability was significantly improved by the incorporation of $\mathrm{Fe}^{\mathrm{II}_{2}}\left[\mathrm{Ru}^{\mathrm{II}}(\mathrm{CN})_{6}\right]$ into

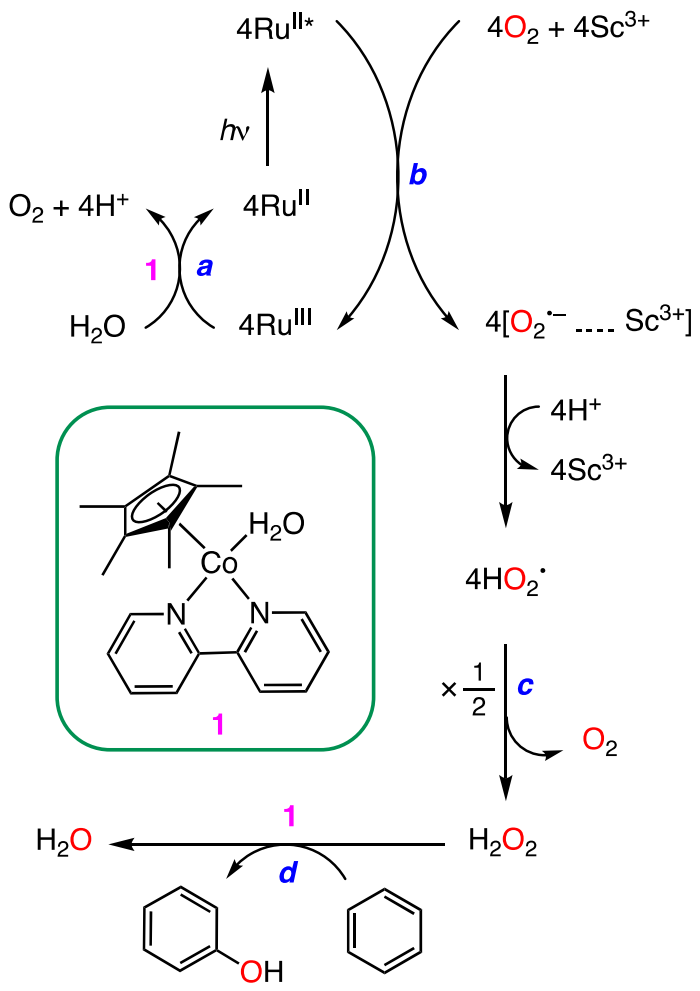

Scheme 8. Proposed mechanism of photocatalytic hydroxylation of benzene by combining photodriven production of $\mathrm{H}_{2} \mathrm{O}_{2}$ via $4 \mathrm{e}^{-} / 4 \mathrm{H}^{+} \mathrm{H}_{2} \mathrm{O}$ oxidation and $2 \mathrm{e}^{-} / 2 \mathrm{H}^{+} \mathrm{O}_{2}$ reduction with benzene hydroxylation by $\mathrm{H}_{2} \mathrm{O}_{2}$ using $\left[\mathrm{Ru}^{\mathrm{II}}\left(4,7-\mathrm{Me}_{2} \text { phen }\right)_{3}\right]^{2+}$ as a photocatalyst and $\left[\left(\mathrm{Cp}^{*}\right) \mathrm{Co}^{\text {III }}(\mathrm{bpy})\left(\mathrm{H}_{2} \mathrm{O}\right)\right]^{2+}$ as a dual function catalyst for the $4 \mathrm{e}^{-} / 4 \mathrm{H}^{+}$oxidation of water and hydroxylation of benzene. Reproduced from Ref. [129] with permission from Royal Society of Chemistry (Copyright 2017).

sAl-MCM-41. Remarkably, the selectivity of product to phenol was higher than $99 \%$, indicating that no over-oxidation products, such as $p$-benzoquinone, were produced [133]. The TON of the formation of phenol reached 2500 at $114 \mathrm{~h}$ photoirradiation [133].

The proposed catalytic mechanism of photodriven benzene hydroxylation by $\mathrm{O}_{2}$ with $\mathrm{Fe}_{2}{ }_{2}\left[\mathrm{Ru}^{\mathrm{II}}(\mathrm{CN})_{6}\right] @ \mathrm{sAl}-\mathrm{MCM}-41$ in MeCN containing $\mathrm{H}_{2} \mathrm{O}$ is shown in Scheme 9 [133]. Photoexcitation of $\mathrm{Fe}^{\mathrm{II}_{2}}\left[\mathrm{Ru}^{\mathrm{II}}(\mathrm{CN})_{6}\right]$ resulted in ET from $\mathrm{Fe}^{\mathrm{II}} 2\left[\mathrm{Ru}^{\mathrm{II}}(\mathrm{CN})_{6}\right]^{*}$ to $\mathrm{O}_{2}$ with $\mathrm{Sc}^{3+}$ to form $\mathrm{Fe}_{2}{ }_{2}\left[\mathrm{Ru}^{\mathrm{III}}(\mathrm{CN})_{6}\right]^{+}$complex and $\mathrm{O}_{2}{ }^{--}-\mathrm{Sc}^{3+}$ species that disproportionates with $\mathrm{H}^{+}$to produce $\mathrm{H}_{2} \mathrm{O}_{2}$ and $\mathrm{O}_{2}$ [50]. $\mathrm{Fe}^{\mathrm{II}_{2}}\left[\mathrm{Ru}^{\mathrm{III}}(\mathrm{CN})_{6}\right]^{+}$, which exhibits high oxidizing ability $\left(E_{1 / 2}=1.24 \mathrm{~V} v\right.$ s. SHE) [133], can produce phenol by oxidizing

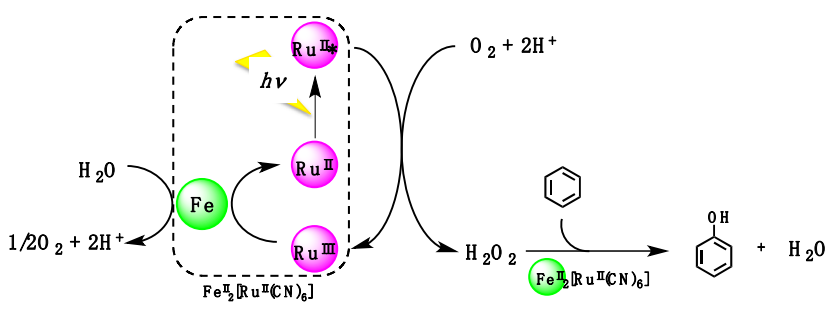

Scheme 9. Coupling of photo- and thermal catalysis by $\mathrm{Fe}_{2}{ }_{2}\left[\mathrm{Ru}^{\mathrm{II}}(\mathrm{CN})_{6}\right] @$ sAl-MCM-41 for photocatalytic hydroxylation of benzene by $\mathrm{O}_{2}$ with $\mathrm{H}_{2} \mathrm{O}$. Reproduced from Ref. [133] with permission from American Chemical Society (Copyright 2016). 


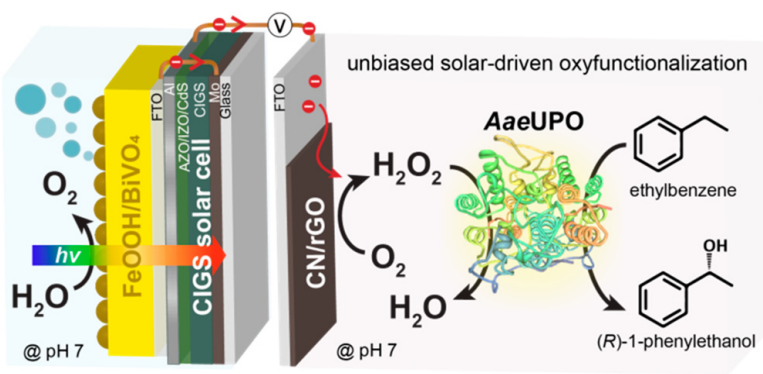

Fig. 8. External bias-free, $\mathrm{PEC} \mathrm{H}_{2} \mathrm{O}_{2}$ production by oxidation of $\mathrm{H}_{2} \mathrm{O}$ by $\mathrm{O}_{2}$ with use of an $\mathrm{FeOOH} / \mathrm{BiVO}_{4} / \mathrm{CIGS}$ solar cell in tandem and $\mathrm{CN} / \mathrm{rGO}$ film electrode under photoirradiation for chemo- and stereospecific conversion of ethylbenzene to obtain $(R)$-1-phenylethanol catalyzed by AaeUPO. Reproduced from Ref. [134] with permission from American Chemical Society (Copyright 2019).

the Fe(II) moiety to a high-valent iron species effective in both oxidation of water and hydroxylation of benzene with $\mathrm{H}_{2} \mathrm{O}_{2}$ [133].

The catalytic oxidation of organic substrates with $\mathrm{H}_{2} \mathrm{O}_{2}$ combined with the photocatalytic $\mathrm{H}_{2} \mathrm{O}_{2}$ production by oxidation of $\mathrm{H}_{2} \mathrm{O}$ by $\mathrm{O}_{2}$ provides a new strategy to achieve one-pot oxygenation of substrates using $\mathrm{O}_{2}$ as the greenest oxidant and $\mathrm{H}_{2} \mathrm{O}$ as the most environmentally benign oxygen source.

An unbiased photoelectrochemical (PEC) tandem cell composed of a $\mathrm{FeOOH} / \mathrm{BiVO}_{4}$ photoanode, a $\mathrm{Cu}(\mathrm{In}, \mathrm{Ga}) \mathrm{Se}_{2}$ solar absorber, and a graphitic carbon nitride/reduced graphene oxide hybrid cathode (Fig. 8) was developed to achieve photocatalytic stereoselective ethylbenzene hydroxylation to obtain (R)-1-phenylethanol with TONs larger than $4.3 \times 10^{4}$, a TOF (turnover frequency) of $12.9 \mathrm{~s}^{-1}$ and high enantioselectivity (ee $>99 \%$ ) [134]. A sufficient photovoltage is generated by the solar absorber, producing $\mathrm{H}_{2} \mathrm{O}_{2}$ in situ by $2 \mathrm{e}^{-} / 2 \mathrm{H}^{+}$reduction of $\mathrm{O}_{2}$ combined with $2 \mathrm{e}^{-} / 2 \mathrm{H}^{+}$oxidation of $\mathrm{H}_{2} \mathrm{O}$ in the absence of external bias. As a counter electrode in the PEC tandem cell, graphitic carbon nitride $(\mathrm{CN})$ and reduced graphene oxide (rGO) hybrid film was used as an effective cathode material for the $2 \mathrm{e}^{-} / 2 \mathrm{H}^{+}$reduction of $\mathrm{O}_{2}$ using electrons extracted from water oxidation at the $\mathrm{BiVO}_{4}$ photoanode [132]. In order to increase the electrochemical active surface area, rGO was used as a supporting layer for $\mathrm{CN}$ [135]. The recombinant peroxygenase from Agrocybe aegerita (AaeUPO) catalyzed selectively the ethylbenzene hydroxylation with $\mathrm{H}_{2} \mathrm{O}_{2}$ to yield (R)-1-phenylethanol [134]. Thus, integration of unbiased PEC system with peroxygenases has been demonstrated to promote $\mathrm{C}-\mathrm{H}$ oxyfunctionalization using solar-powered electrons extracted from $\mathrm{H}_{2} \mathrm{O}$.

\section{Conclusion and perspective}

Combination of $2 \mathrm{e}^{-} / 2 \mathrm{H}^{+}$reduction of $\mathrm{O}_{2}$ with photodriven $4 \mathrm{e}^{-} / 4 \mathrm{H}^{+}$oxidation of $\mathrm{H}_{2} \mathrm{O}$ resulted in photocatalytic $\mathrm{H}_{2} \mathrm{O}_{2}$ production by oxidation of $\mathrm{H}_{2} \mathrm{O}$ by $\mathrm{O}_{2}$. A homogeneous photocatalytic system for photodriven production of $\mathrm{H}_{2} \mathrm{O}_{2}$ by oxidation of $\mathrm{H}_{2} \mathrm{O}$ by $\mathrm{O}_{2}$ is composed of a $\mathrm{Ru}(\mathrm{II})$ complex acting as a photoredox catalyst for $2 \mathrm{e}^{-} / 2 \mathrm{H}^{+} \mathrm{O}_{2}$ reduction to produce $\mathrm{H}_{2} \mathrm{O}_{2}$ and a $\mathrm{Co}(\mathrm{III})$ complex acting as a redox catalyst for $4 \mathrm{e}^{-} / 4 \mathrm{H}^{+} \mathrm{H}_{2} \mathrm{O}$ oxi- dation to evolve $\mathrm{O}_{2}$. Heterogeneous photocatalysts for water oxidation can also be used to be combined with a Co(III) chlorin complex for $2 \mathrm{e}^{-} / 2 \mathrm{H}^{+} \mathrm{O}_{2}$ reduction to achieve photodriven production of $\mathrm{H}_{2} \mathrm{O}_{2}$ by oxidation of $\mathrm{H}_{2} \mathrm{O}$ by $\mathrm{O}_{2}$. Both $2 \mathrm{e}^{-} / 2 \mathrm{H}^{+} \mathrm{H}_{2} \mathrm{O}$ oxidation and $2 \mathrm{e}^{-} / 2 \mathrm{H}^{+} \mathrm{O}_{2}$ reduction yield $\mathrm{H}_{2} \mathrm{O}_{2}$ simultaneously. Thus, simultaneous $\mathrm{H}_{2} \mathrm{O}_{2}$ production by the $2 \mathrm{e}^{-} / 2 \mathrm{H}^{+} \mathrm{H}_{2} \mathrm{O}$ oxidation and the $2 \mathrm{e}^{-} / 2 \mathrm{H}^{+} \mathrm{O}_{2}$ reduction has been achieved using a single photocatalyst sheet without separation of anode and cathode solutions under simulated solar-light illumination. $\mathrm{H}_{2} \mathrm{O}_{2}$ produced by photodriven $\mathrm{H}_{2} \mathrm{O}$ oxidation by $\mathrm{O}_{2}$ is used as a fuel in $\mathrm{H}_{2} \mathrm{O}_{2}$ fuel cells to obtain electricity. Solar-light-driven production of $\mathrm{H}_{2} \mathrm{O}_{2}$ by $\mathrm{H}_{2} \mathrm{O}$ oxidation by $\mathrm{O}_{2}$ is also combined with green oxidation of organic substrates with $\mathrm{H}_{2} \mathrm{O}_{2}$ when $\mathrm{O}_{2}$ is used as the greenest oxidant and $\mathrm{H}_{2} \mathrm{O}$ as the most environmentally benign oxygen source. The best solar-to- $\mathrm{H}_{2} \mathrm{O}_{2}$ energy conversion efficiency has so far been limited to $6.6 \%$ and $0.89 \%$ under 0.05 sun and 1 sun, respectively [79]. The further improvement of the efficiency of solar-light-driven production of $\mathrm{H}_{2} \mathrm{O}_{2}$ will be made by the combination of $2 \mathrm{e}^{-} / 2 \mathrm{H}^{+} \mathrm{H}_{2} \mathrm{O}$ oxidation and $2 \mathrm{e}^{-} / 2 \mathrm{H}^{+} \mathrm{O}_{2}$ reduction, facilitating the use of $\mathrm{H}_{2} \mathrm{O}_{2}$ as a solar fuel in fuel cells as well as a green oxidant.

\section{Acknowledgments}

The authors gratefully acknowledge the contributions of their collaborators and coworkers mentioned in the cited references.

\section{References}

[1] J. M. Campos-Martin, G. Blanco-Brieva, J. L. G. Fierro, Angew. Chem. Int. Ed., 2006, 45, 6962-6984.

[2] R. N. Gurram, M. Al-Shannag, N. Joshua Lecher, S. M. Duncan, E. L. Singsaas, M. Alkasrawi, Bioresource Technol., 2015, 192, 529-539.

[3] M. Kisibi, Chem. Eng. J., 2006, 119, 161-165.

[4] M. F. Khan, L. Yu, J. Hollman, J. H. Tay, G. Achari, Environ. Sci.: Water Res. Technol., 2020, 6, 1711-1722.

[5] G. Daniel, Y. Zhang, S. Lanzalaco, F. Brombin, T. Kosmala, G. Granozzi, A. Wang, E. Brillas, I. Sirés, C. Durante, ACS Sustainable Chem. Eng., 2020, 8, 14425-14440.

[6] P. V. Nidheesh, J. Scaria, D. S. Babu, M. S. Kumar, Chemosphere, 2021, 263, 127907.

[7] B. S. Lane, K. Burgess, Chem. Rev., 2003, 103, 2457-2473.

[8] R. Ciriminna, L. Albanese, F. Meneguzzo, M. Pagliaro, ChemSusChem, 2016, 9, 3374-3381.

[9] C. Wang, H. Yamamoto, Chem. Asian J., 2015, 10, 2056-2068.

[10] M. Hu, W. Wu, H. Jiang, ChemSusChem, 2019, 12, 2911-2935.

[11] M. Oszajca, M. Brindell, Ł. Orzeł, J. M. Dąbrowski, K. Śpiewak, P. Łabuz, M. Pacia, A. Stochel-Gaudyn, W. Macyk, R. van Eldik, G. Stochel, Coord. Chem. Rev., 2016, 327-328, 143-165.

[12] Y. Yang, R. Dong, Y. Zhu, H. Li, H. Zhang, X. Fan, H. Chang, Chem. Eng.J., 2020, 381, 122749.

[13] Z. Liu, D. Ye, S. Wang, X. Zhu, R. Chen, Q. Liao, Ind. Eng. Chem. Res., 2020, 59, 15447-15453.

[14] Y. Yang, H. Zhang, J. Wang, S. Yang, T. Liu, K. Tao, H. Chang, J. Mater. Chem. A, 2019, 7, 11497-11505.

[15] S. Fukuzumi, Joule, 2017, 1, 689-738.

[16] C. J. McDonnell-Worth, D. R. MacFarlane, Aust. J. Chem., 2018, 71, 781-788. 


\section{Graphical Abstract}

Chin. J. Catal., 2021, 42: 1241-1252 doi: 10.1016/S1872-2067(20)63767-6

Recent progress in production and usage of hydrogen peroxide

Shunichi Fukuzumi*, Yong-Min Lee *, Wonwoo Nam*

Ewha Womans University, Korea; Meijo University, Japan

This review focuses on recent progress in solar-light-driven $\mathrm{H}_{2} \mathrm{O}_{2}$ production by oxidation of $\mathrm{H}_{2} \mathrm{O}$ and by reduction of $\mathrm{O}_{2}$ as well as the usage of $\mathrm{H}_{2} \mathrm{O}_{2}$ as a green oxidant and fuel.

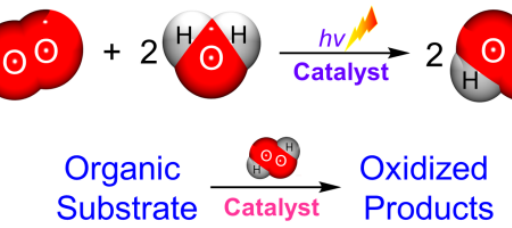

[17] S. Fukuzumi, Y. Yamada, ChemElectroChem, 2016, 3, 1978-1989.

[18] L. An, T. Zhao, X. Yan, X. Zhou, P. Tan, Sci. Bull., 2015, 60, 55-64.

[19] S. Fukuzumi, Y. Yamada, Aust. J. Chem., 2014, 67, 354-364.

[20] S. Fukuzumi, Y. Yamada, K. D. Karlin, Electrochim. Acta, 2012, 82, 493-511.

[21] G. Gao, Y. Tian, X. Gong, Z. Pan, K. Yang, B. Zong, Chin. J. Catal., 2020, 41, 1039-1047

[22] H. Li, B. Zheng, Z. Pan, B. Zong, M. Qiao, Front. Chem. Sci. Eng., 2018, 12, 124-131.

[23] J. García-Serna, T. Moreno, P. Biasi, M. J. Cocero, J.-P. Mikkola, T. O. Salmi, Green Chem., 2014, 16, 2320-2343.

[24] J. K. Edwards, B. Solsona, E. N. Ntainjua, A. F. Carley, A. A. Herzing, C. J. Kiely, G. J. Hutchings, Science, 2009, 323, 1037-1041.

[25] J. K. Edwards, S. J. Freakley, A. F. Carley, C. J. Kiely, G. J. Hutchings, Acc. Chem. Res., 2014, 47, 845-854.

[26] J. K. Edwards, S. J. Freakley, R. J. Lewis, J. C. Pritchard, G. J. Hutchings, Catal. Today, 2015, 248, 3-9.

[27] D. W. Flaherty, ACS Catal., 2018, 8, 1520-1527.

[28] R. J. Lewis, G. J. Hutchings, ChemCatChem, 2019, 11, 298-308.

[29] F. Menegazzo, M. Signoretto, E. Ghedini, G. Strukul, Catalysts, 2019, 9, 251.

[30] S. G. Peera, H. J. Kwon, T. G. Lee, J. Balamurugan, A. M. Hussain, ACS Symp. Ser., 2020, 1342, 231-278.

[31] X. X. Wang, J. Sokolowski, H. Liu, G. Wu, Chin. J. Catal., 2020, 41, 739-755.

[32] Y. He, S. Liu, C. Priest, Q. Shi, G. Wu, Chem. Soc. Rev., 2020, 49, 3484-3524.

[33] E. Jung, H. Shin, W. Hooch Antink, Y.-E. Sung, T. Hyeon, ACS Energy Lett., 2020, 5, 1881-1892.

[34] S. Siahrostami, S. J. Villegas, A. H. B. Mostaghimi, S. Back, A. B. Farimani, H. Wang, K. A. Persson, J. Montoya, ACS Catal., 2020, 10, 7495-7511.

[35] M. Liu, L. Wang, K. Zhao, S. Shi, Q. Shao, L. Zhang, X. Sun, Y. Zhao, J. Zhang, Energy Environ. Sci., 2019, 12, 2890-2923.

[36] A. Sarapuu, E. Kibena-Poldsepp, M. Borghei, K. Tammeveski, J. Mater. Chem. A, 2018, 6, 776-804.

[37] S. Yang, A. Verdaguer-Casadevall, L. Arnarson, L. Silvioli, V. Colic, R. Frydendal, J. Rossmeisl, I. Chorkendorff, I. E. L. Stephens, ACS Catal., 2018, 8, 4064-4081.

[38] C. Xia, Y. Xia, P. Zhu, L. Fan, H. Wang, Science, 2019, 366, 226-231.

[39] H. Hou, X. Zeng, X. Zhang, Angew. Chem. Int. Ed., 2020, 59, 17356-17376.
[40] P. Zhang, Y. Tong, Y. Liu, J. J. M. Vequizo, H. Sun, C. Yang, A. Yamakata, F. Fan, W. Lin, X. Wang, W. Choi, Angew. Chem. Int. Ed., 2020, 59, 16209-16217.

[41] Y. Sun, L. Han, P. Strasser, Chem. Soc. Rev., 2020, 49, 6605-6631.

[42] X. Hu, X. Zeng, Y. Liu, J. Lu, X. Zhang, Nanoscale, 2020, 12, 16008-16027.

[43] Z. Haider, H.-I. Cho, G.-H. Moon, H.-I. Kim, Catal. Today, 2019, 335, 55-64.

[44] A. Torres-Pinto, M. J. Sampaio, C. G. Silva, J. L. Faria, A. M. T. Silva, Catalysts, 2019, 9, 990.

[45] S. Fukuzumi, Y.-M. Lee, W. Nam, Chem.-Eur. J., 2018, 24, 5016-5031.

[46] S. Fukuzumi, Y.-M. Lee, W. Nam, ChemPhotoChem, 2018, 2, 121-135.

[47] Y.-X. Ye, C. Wen, J. Pan, J.-W. Wang, Y.-J. Tong, S. Wei, Z. Ke, L. Jiang, F. Zhu, M. Zhou, J. Xu, G. Ouyang, Appl. Catal. B, 2021, 285, 119726.

[48] H. Song, L. Wei, L. Chen, H. Zhang, J. Su, Top. Catal., 2020, 63, 895-912.

[49] X. Zeng, Y. Liu, Y. Kang, Q. Li, Y. Xia, Y. Zhu, H. Hou, M. H. Uddin, T. R. Gengenbach, D. Xia, C. Sun, D. T. Mccarthy, A. Deletic, J. Yu, X. Zhang, ACS Catal., 2020, 10, 3697-3706.

[50] S. Kato, J. Jung, T. Suenobu, S. Fukuzumi, Energy Environ. Sci., 2013, 6, 3756-3764.

[51] S. Fukuzumi, Y.-M. Lee, W. Nam, Dalton Trans., 2019, 48, 779-798.

[52] S. I. Shylin, M. V. Pavliuk, L. D’Amario, I. O. Fritsky, G. Berggren, Faraday Discuss., 2019, 215, 162-174.

[53] M. A. Asraf, C. I. Ezugwu, C. M. Zakaria, F. Verpoort, Photochem. Photobiol. Sci., 2019, 18, 2782-2791.

[54] Q. Han, Y. Ding, Dalton Trans., 2018, 47, 8180-8188.

[55] X. Liang, X. Cao, W. Sun, Y. Ding, ChemCatChem, 2019, 11, 6190-6202.

[56] B. M. Hunter, H. B. Gray, A. M. Muller, Chem. Rev., 2016, 116, 14120-14136.

[57] Y. Yamada, K. Oyama, T. Suenobu, S. Fukuzumi, Chem. Commun., 2017, 53, 3418-3421.

[58] M. D. Kaerkaes, B. Aakermark, Dalton Trans., 2016, 45, 14421-14461.

[59] S. Fukuzumi, J. Jung, Y. Yamada, T. Kojima, W. Nam, Chem. Asian J., 2016, 11, 1138-1150.

[60] A. F. Abdel-Magied, A. Shatskiy, R.-Z. Liao, T. M. Laine, W. A. A. Arafa, P. E. M. Siegbahn, M. D. Kärkäs, B. Åkermark, E. V. Johnston, ChemSusChem, 2016, 9, 3448-3456. 
[61] C. Panda, J. Debgupta, D. D. Díaz, K. K. Singh, S. Sen Gupta, B. B. Dhar, J. Am. Chem. Soc., 2014, 136, 12273-12282.

[62] S. Fukuzumi, M. Patz, T. Suenobu, Y. Kuwahara, S. Itoh, J. Am. Chem. Soc., 1999, 121, 1605-1606.

[63] S. Fukuzumi, K. Ohkubo, Chem.-Eur. J., 2000, 6, 4532-4535.

[64] S. Fukuzumi, K. Ohkubo, Y.-M. Lee, W. Nam, Chem.-Eur. J., 2015, 21, 17548-17559.

[65] D. Hong, Y. Yamada, T. Nagatomi, Y. Takai, S. Fukuzumi, J. Am. Chem. Soc., 2012, 134, 19572-19575.

[66] Y. Isaka, S. Kato, D. Hong, T. Suenobu, Y. Yamada, S. Fukuzumi, J. Mater. Chem. A, 2015, 3, 12404-12412.

[67] Y. Isaka, K. Oyama, Y. Yamada, T. Suenobu, S. Fukuzumi, Catal. Sci. Technol., 2016, 6, 681-684.

[68] Y. Aratani, T. Suenobu, K. Ohkubo, Y. Yamada, S. Fukuzumi, Chem. Commun., 2017, 53, 3473-3476.

[69] Y. Isaka, Y. Yamada, T. Suenobu, T. Nakagawa, S. Fukuzumi, RSC Adv., 2016, 6, 42041-42044.

[70] Y. Wang, W. Tian, C. Chen, W. Xu, L. Li, Adv. Funct. Mater., 2019, 29, 1809036.

[71] X. Liu, F. Wang, Q. Wang, Phys. Chem. Chem. Phys., 2012, 14, 7894-7911.

[72] Y. Park, K. J. McDonald, K.-S. Choi, Chem. Soc. Rev., 2013, 42, 2321-2337.

[73] P. Luan, J. Zhang, ChemElectroChem, 2019, 6, 3227-3243.

[74] J. A. Seabold, K. S. Choi, J. Am. Chem. Soc., 2012, 134, 2186-2192.

[75] T. W. Kim, K. S. Choi, Science, 2014, 343, 990-994.

[76] B. J. Trześniewski, O. Diaz-Morales, D. A. Vermaas, A. Longo, W. Bras, M. T. M. Koper, W. A. Smith, J. Am. Chem. Soc., 2015, 137, 15112-15121.

[77] K. Mase, K. Ohkubo, S. Fukuzumi, J. Am. Chem. Soc., 2013, 135, 2800-2808.

[78] K. Mase, K. Ohkubo, S. Fukuzumi, Inorg. Chem., 2015, 54, 1808-1815.

[79] K. Mase, M. Yoneda, Y. Yamada, S. Fukuzumi, ACS Energy Lett., 2016, 1, 913-919.

[80] A. Melis, Plant Sci., 2009, 177, 272-280.

[81] K. Mase, M. Yoneda, Y. Yamada, S. Fukuzumi, Nat. Commun., 2016, 7, 11470 .

[82] S. Nakagawara, T. Goto, M. Nara, Y. Ozawa, K. Hotta, Y. Arata, Anal. Sci., 1998, 14, 691-698.

[83] L. Huang, R. Li, R. Chong, G. Liu, J. Han, C. Li, Catal. Sci. Technol,, 2014, 4, 2913-2918.

[84] M. Teranishi, S.-I. Naya, H. Tada, J. Am. Chem. Soc., 2010, 132, 7850-7851.

[85] D. Tsukamoto, A. Shiro, Y. Shiraishi, Y. Sugano, S. Ichikawa, S. Tanaka, T. Hirai, ACS Catal., 2012, 2, 599-603.

[86] L. Zheng, H. Su, J. Zhang, L. Walekar, H. V. Molamahmood, B. Zhou, M. Long, Y. Hu, Appl. Catal. B, 2018, 239, 475-484.

[87] L. Zheng, J. Zhang, Y. H. Hu, M. Long, J. Phys. Chem. C, 2019, 123, 13693-13701.

[88] J. Zhang, L. Zheng, F. Wang, C. Chen, H. Wu, S. A. K. Leghari, M. Long, Appl. Catal. B, 2020, 269, 118770.

[89] B. O. Burek, D. W. Bahnemann, J. Z. Bloh, ACS Catal., 2019, 9, 25-37.

[90] Y. Shiraishi, Y. Kofuji, H. Sakamoto, S. Tanaka, S. Ichikawa, T. Hirai, ACS Catal., 2015, 5, 3058-3066.

[91] Z. Teng, W. Cai, W. Sim, Q. Zhang, C. Wang, C. Su, T. Ohno, Appl. Catal. B, 2021, 282, 119589.

[92] Y. Shiraishi, S. Kanazawa, Y. Sugano, D. Tsukamoto, H. Sakamoto, S. Ichikawa, T. Hirai, ACS Catal., 2014, 4, 774-780.

[93] Y. Cui, Z. Ding, P. Liu, M. Antonietti, X. Fu, X. Wang, Phys. Chem. Chem. Phys., 2012, 14, 1455-1462.
[94] J. Chen, P. Wagner, L. Tong, G. G. Wallace, D. L. Officer, G. F. Sweigers, Angew. Chem. Int. Ed., 2012, 51, 1907-1910.

[95] W. H. Koppenol, J. Am. Chem. Soc., 2007, 129, 9686-9690.

[96] S. Chu, Y. Wang, Y. Guo, J. Feng, C. Wang, W. Luo, X. Fan, Z. Zou, ACS Catal., 2013, 3, 912-919.

[97] Y. Shiraishi, S. Kanazawa, Y. Kofuji, H. Sakamoto, S. Ichikawa, S. Tanaka, T. Hirai, Angew. Chem. Int. Ed., 2014, 53, 13454-13459.

[98] Y. Kofuji, Y. Isobe, Y. Shiraishi, H. Sakamoto, S. Tanaka, S. Ichikawa, T. Hirai, J. Am. Chem. Soc., 2016, 138, 10019-10025.

[99] Y. Shiraishi, T. Takii, T. Hagi, S. Mori, Y. Kofuji, Y. Kitagawa, S. Tanaka, S. Ichikawa, T. Hirai, Nat. Mater., 2019, 18, 985-993.

[100] M. M. Najafpour, G. Renger, M. Hołyńska, A. N. Moghaddam, E.-M. Aro, R. Carpentier, H. Nishihara, J. J. Eaton-Rye, J.-R. Shen, S. I. Allakhverdiev, Chem. Rev., 2016, 116, 2886-2936.

[101] J.-R. Shen, Annu. Rev. Plant Biol., 2015, 66, 23-48.

[102] Y. H. Hong, J. Jung, T. Nakagawa, N. Sharma, Y.-M. Lee, W. Nam, J. Am. Chem. Soc., 2019, 141, 6748-6754.

[103] K. Ohkubo, A. Fujimoto, S. Fukuzumi, J. Am. Chem. Soc., 2013, 135, 5368-5371.

[104] K. Ohkubo, K. Hirose, S. Fukuzumi, Chem.-Eur. J., 2015, 21, 2855-2861.

[105] Y. Liu, Y. Han, Z. Zhang, W. Zhang, W. Lai, Y. Wang, R. Cao, Chem. Sci., 2019, 10, 2613-2622.

[106] Y. Miyase, Y. Miseki, T. Gunji, K. Sayama, ChemElectroChem, 2020, 7, 2448-2455.

[107] R. Saito, Y. Miseki, K. Sayama, Chem. Commun., 2012, 48, 3833-3835.

[108] I. Fujimoto, N. Wang, R. Saito, Y. Miseki, T. Gunji, K. Sayama, Int. J. Hydrogen Energy, 2014, 39, 2454-2461.

[109] X. Shi, I. Y. Choi, K. Zhang, J. Kwon, D. Y. Kim, J. K. Lee, S. H. Oh, J. K. Kim, J. H. Park, Nat. Commun., 2014, 5, 4775.

[110] K. Fuku, K. Sayama, Chem. Commun., 2016, 52, 5406-5409.

[111] K. Fuku, Y. Miyase, Y. Miseki, T. Funaki, T. Gunji, K. Sayama, Chem. Asian J., 2017, 12, 1111-1119.

[112] Y. Miyase, S. Takasugi, S. Iguchi, Y. Miseki, T. Gunji, K. Sasaki, E. Fujita, K. Sayama, Sustainable Energy Fuels, 2018, 2, 1621-1629.

[113] Y. Yamada, M. Yoneda, S. Fukuzumi, Energy Environ. Sci., 2015, 8, 1698-1701.

[114] J. Ji, Y. Chung, Y. Kwon, J. Mater. Chem. C, 2020, 8, 2749-2755.

[115] E. Miglbauer, P. J. Wójcikc, E. D. Głowacki, Chem. Commun., 2018, 54, 11873-11876.

[116] S. M. Ha, Y. Ahn, J. Power Sources, 2014, 267, 731-738.

[117] S. M. Mousavi Ehteshami, M. Asadnia, S. N. Tan, S. H. Chan, J. Power Sources, 2016, 301, 392-395.

[118] M. Asadnia, S. M. M. Ehteshami, S. H. Chan, M. E. Warkiani, RSC Adv., 2017, 7, 40755-40760.

[119] Y. Yang, Y. S. Xue, F. Huang, H. Zhang, K. Tao, R. R. Zhang, Q. Shen, H. L. Chang, ACS Appl. Energy Mater., 2018, 1, 5328-5335.

[120] X. H. Yan, A. Xu, L. Zeng, P. Gao, T. S. Zhao, Energy Technol., 2018, 6, 140-143.

[121] Y. Yang, Y. S. Xue, H. Zhang, H. L. Chang, Chem. Eng. J., 2019, 369, 813-817.

[122] L. Vicens, G. Olivo, M. Costas, ACS Catal., 2020, 10, 8611-8631.

[123] M. C. White, J. Zhao, J. Am. Chem. Soc., 2018, 140, 13988-14009.

[124] G. Olivo, O. Cussó, M. Borrell, M. Costas, J. Biol. Inorg. Chem., 2017, 22, 425-452.

[125] J. Serrano-Plana, C. Rumo, J. G. Rebelein, R. L. Peterson, M. Barnet, T. R. Ward, J. Am. Chem. Soc., 2020, 142, 10617-10623.

[126] R. V. Ottenbacher, E. P. Talsi, K. P. Bryliakov, J. Catal., 2020, 390, 170-177.

[127] J. Chen, Z. Jiang, S. Fukuzumi, W. Nam, B. Wang, Coord. Chem. 
Rev., 2020, 421, 213443.

[128] L. Ma, Y. Pan, W.-L. Man, H.-K. Kwong, W. W. Y. Lam, G. Chen, K.-C. Lau, T.-C. Lau, J. Am. Chem. Soc., 2014, 136, 7680-7687.

[129] J. W. Han, J. Jung, Y.-M. Lee, W. Nam, S. Fukuzumi, Chem. Sci., 2017, 8, 7119-7125.

[130] T. D. Bui, A. Kimura, S. Ikeda, M. Matsumura, J. Am. Chem. Soc., 2010, 132, 8453-8458.

[131] Y. Ide, M. Torii, T. Sano, J. Am. Chem. Soc., 2013, 135,
11784-11786.

[132] K. Ohkubo, T. Kobayashi, S. Fukuzumi, Angew. Chem., Int. Ed., 2011, 50, 8652-8655.

[133] Y. Aratani, K. Oyama, T. Suenobu, Y. Yamada, S. Fukuzumi, Inorg. Chem., 2016, 55, 5780-5786.

[134] D. S. Choi, H. Lee, F. Tieves, Y. W. Lee, E. J. Son, W. Zhang, B. Shin, F. Hollmann, C. B. Park, ACS Catal., 2019, 9, 10562-10566.

[135] W. Niu, Y. Yang, ACS Energy Lett., 2018, 3, 2796-2815.

\title{
过氧化氢生产与利用的新进展
}

\author{
Shunichi Fukuzumi ${ }^{\text {a,b,*, }}$, Yong-Min Lee ${ }^{\text {a,c,\# }, \text { Wonwoo Nam }}{ }^{\text {a,\$ }}$ \\ 梨花女子大学化学与纳米科学系, 首尔, 韩国

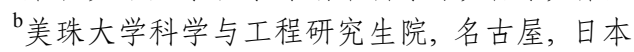 \\ “梨花女子大学基础科学研究院, 首尔, 韩国
}

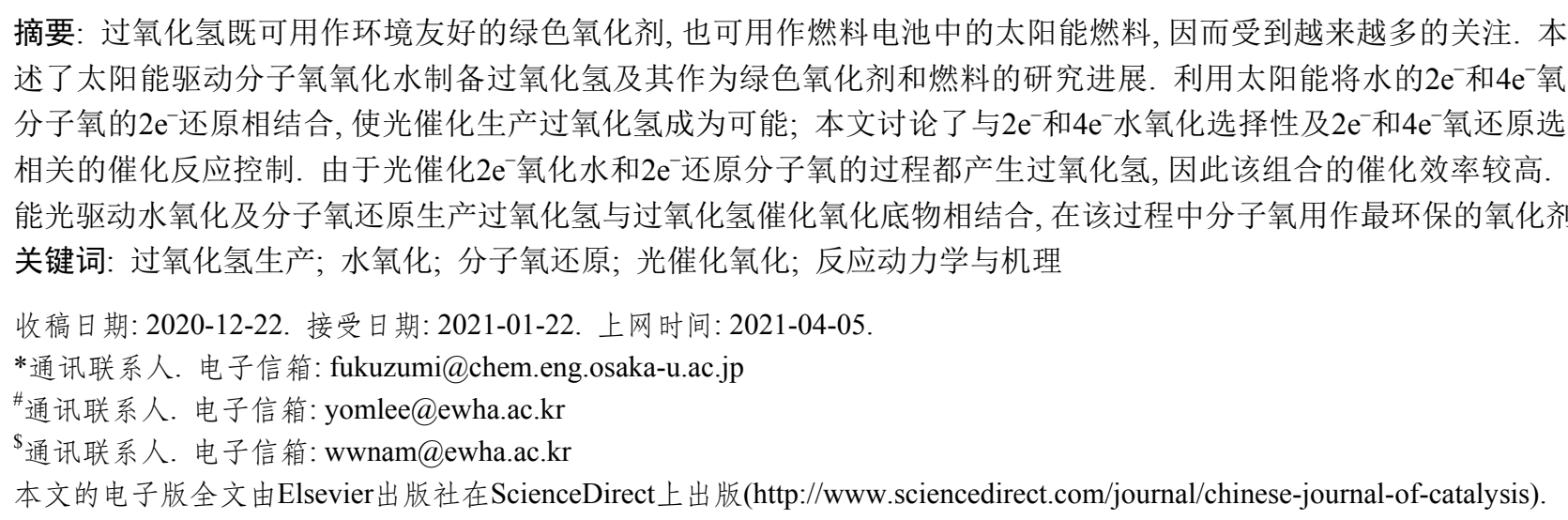

